\title{
Morphological differentiation of Peromyscus leucopus and P. maniculatus in East Texas
}

\author{
Jessica E. Light ${ }^{1,2 *}$, Leila Siciliano-Martina ${ }^{2,3}$, Emma G. Dohlanik ${ }^{1}$, Grace Vielleux¹, David J. Hafner ${ }^{4}$, A. Michelle LaWing ${ }^{1,2}$, and Ira F. Greenbaum²,5 \\ 'Department of Ecology and Conservation Biology, Texas A\&M University, College Station, 77843, Texas, USA. Email: jlight2@tamu.edu, \\ dohn51@tamu.edu, ginge@tamu.edu, alawing@tamu.edu. \\ ${ }^{2}$ Interdisciplinary Program in Ecology \& Evolutionary Biology, Texas A\&M University, College Station, 77843, Texas, USA. \\ ${ }^{3}$ Department of Biology, Texas State University, San Marcos, 78666, Texas, USA. Email: sicilia.marti@gmail.com. \\ ${ }^{4}$ Museum of Southwestern Biology, University of New Mexico, Albuquerque, 87131, New Mexico, USA. Email: dhafner@unm.edu. \\ ${ }^{5}$ Department of Biology, Texas A\&M University, College Station, 77843, Texas, USA. Email: i-greenbaum@tamu.edu. \\ ${ }^{*}$ Corresponding author
}

The white-footed deer mouse (Peromyscus leucopus) and the North American deer mouse (P. maniculatus) are widely distributed throughout North America, often with overlapping distributions. These species are believed to be sympatric east of the Balcones fault zone in Texas, but records from natural history collections indicate that $P$. maniculatus is not common from this region. Given that these two species are notoriously difficult to differentiate morphologically, it is possible that specimens have been incorrectly identified and that $P$. maniculatus may be rare or not present in East Texas. This study aims to determine if $P$. leucopus and $P$. maniculatus can be differentiated morphologically east of the Balcones fault zone in Texas. Cranial and external characters from genetically identified specimens representing each species were analyzed using traditional and geometric morphometric methods. Morphological analyses revealed that genetically identified specimens of $P$. leucopus and P. maniculatus from east of the Balcones fault zone could be differentiated using a suite of morphological characters. Many of the specimens of $P$. leucopus used in this study were originally misidentified, suggesting that $P$. maniculatus is rare in East Texas.

El ratón ciervo de patas blancas (Peromyscus leucopus) y el ratón ciervo norteamericano (P. maniculatus) estan ampliamente distribuidos por toda Norteamérica, frecuentemente con distribuciones superpuestas. Se cree que en la región este de la falla de Balcones, Texas estas especies son simpátricas, pero los registros de su historia natural indican que $P$. maniculatus no es común en esta región. Debido a que estas dos especies son notoriamente difíciles de diferenciar morfológicamente, es posible que los especímenes hayan sido identificados incorrectamente y que P. maniculatus sea rara o pueda no estar presente en el este de Texas. Este estudio pretende determinar si P. leucopus y P. maniculatus pueden diferenciarse morfológicamente en la zona del este de la falla de Balcones, Texas. Los caracteres craneales y externos de especímenes identificados genéticamente que representan cada especie fueron analizados utilizando métodos morfométricos tradicionales y geométricos. Los análisis morfológicos revelaron que los especímenes genéticamente identifacados de $P$. leucopus y $P$. maniculatus del este de la zona de la falla de Balcones podrían diferenciarse utilizando un conjunto de caracteres morfológicos. Muchos de los especímenes de $P$. leucopus usados en este estudio fueron identificados erróneamente, lo que sugiere que P. maniculatus es raro en el este de Texas.

Keywords: Balcones fault zone; geometric morphometrics; species differentiation; traditional morphometrics.

(c) 2021 Asociación Mexicana de Mastozoología, www.mastozoologiamexicana.org

\section{Introduction}

Rodents belonging to the genus Peromyscus have been called the "Drosophila of North American mammalogy" (Musser and Carleton 1993), and as a model system, they have long been the focus of ecological, evolutionary, systematic, and biogeographic research (e. g., King 1968; Harney and Dueser 1987; Kirkland and Layne 1989; Wolff 1996; Berl et al. 2017; Bedford and Hoekstra 2015; Lewarch and Hoekstra 2018). Peromyscus species also are of publichealth interest due to their ability to serve as reservoirs for a variety of pathogens and viruses, such as hantaviruses and Lyme disease, that can be transmitted to humans (e.g., Rand et al. 1993; Childs et al. 1994; Schmaljohn et al. 1995; Song et al. 1996; Drebot et al. 2001; Oliver et al. 2006; Larson et al. 2018). Given the importance of these species to a wide variety of scientific fields, it is essential to identify and differentiate Peromyscus species accurately. However, these ecologically and medically important species are morphologically variable across their geographic range (Dice 1940), thus making accurate identification difficult.
Rigorous analytical techniques may be necessary to differentiate morphologically similar taxa. Two techniques commonly used to separate organismal groups based on morphology are traditional (linear) morphometrics and two-dimensional (2D) geometric morphometrics. Traditional morphometrics focus on linear-distance measurements of traits (usually obtained using calipers) and often incorporate size components. In contrast, geometric morphometrics is a method that primarily captures variation in shape (Rohlf and Slice 1990; Slice 2007) and requires advanced imaging of specimens from various views (e. g., ventral, dorsal, and lateral views) followed by careful placement of morphological landmarks on the image. The geometric relationships of these landmarks are then analyzed, allowing an independent analysis of shape after removing the influence of size, position, and orientation in landmark data (Rohlf and Marcus 1993; Adams et al. 2004). Geometric morphometrics are believed to have multiple benefits over traditional morphometric approaches, such as better visualization of among-group differences and provision of addi- 
tional information for analysis (Breno et al. 2011). Traditional morphometrics, however, are generally more readily accessible in terms of data acquisition and have a demonstrated record of successfully differentiating taxa morphologically.

Two Peromyscus species that have been the subject of many studies involving morphological differentiation are the white-footed deer mouse (P. leucopus) and the North American deer mouse ( $P$. maniculatus sensu lato; Bradley et al. 2019; Greenbaum et al. 2019). These species are distributed widely throughout North America, often with overlapping distributions (Kirkland and Layne 1989). Although not close phylogenetic relatives (Platt et al. 2015) and placed in different (but sister) species groups, $P$. leucopus and $P$. maniculatus are morphologically similar (Hall 1981), with tail length, extent of tail bicoloration, pelage color, hindfoot length, and ear size commonly used to differentiate these two species (e. g., Palas et al. 1992; Bruseo et al. 1999). However, both external (e. g., tail length) and cranial characters are geographically variable (e. g., Osgood 1909; Choate 1973; Choate et al. 1979; Hall 1981; Dalquest and Stangl 1983; Myers et al. 1996; Pergams and Ashley 1999; Pergams and Lacy 2008; Grieco and Rizk 2010; Holmes et al. 2016; Millien et al. 2017). This geographic variation may result in higher likelihoods of species misidentification. Thus, genetic or molecular means of identification is often necessary to confidently identify morphologically similar species such as P. leucopus and P. maniculatus (e. g., Aquadro and Patton 1980; Feldhamer et al. 1983; Rich et al. 1996; Sternburg and Feldhamer 1997; Bruseo et al. 1999; Reed et al. 2004; Tessier et al. 2004; Ridenhour and Cramer 2015; Seifert et al. 2016).

In Texas, the distributions of $P$. leucopus and P. maniculatus are thought to overlap throughout much of the state, often making species identification difficult (Schmidly and Bradley 2016). An examination of specimens on VertNet (9 November 2020) suggests that $P$. leucopus is far more common throughout the state than P. maniculatus (Figure 1). For example, there are 8,350 specimens of $P$. leucopus in collections, compared to 3,603 specimens of $P$. maniculatus, with P. leucopus recorded from 198 of Texas' 254 counties (78 \%; Figure 1a) and $P$. maniculatus recorded from 159 counties (63\%; Figure 1b). The Balcones fault zone (Figure 1) divides the state into distinct western and eastern regions, which are further divided into four regions based on the ecological distribution of mammals: the Trans-Pecos and Plains Country west of the fault zone and East Texas and the Rio Grande Plains including and east of the fault zone (Schmidly 1983; Davis and Schmidly 1994; Schmidly and Bradley 2016; Figure 1c). These regions differ in climate, precipitation, flora, and fauna and many species meet their western or eastern limits at the Balcones fault zone (e. g., Smith and Buechner 1947; Gehlbach 1991). According to Schmidly and Bradley (2016), approximately 18 terrestrial-mammal species occur primarily west of the Balcones fault zone, 13 species principally occur east of the Balcones fault zone, and 31 species (including $P$. leucopus and $P$. maniculatus) are distributed throughout the state. However, specimens from natural history collections, indicate that $P$. maniculatus is less common in East Texas (Figure 1) and is perhaps even rarer than is perceived given the difficulty in accurately identifying Peromyscus species.

A major objective of this study is to determine if $P$. leucopus and P. maniculatus of East Texas can be differentiated morphologically based on reference samples of genetically identified specimens of each species. This study also compares the utility of traditional (linear) and geometric morphometrics for differentiating $P$. leucopus and $P$. maniculatus and describes general morphological variation present in these species from East Texas. Lastly, the distribution of $P$. maniculatus east of the Balcones fault zone will be reassessed.

\section{Materials and Methods}

Specimens examined. Specimens, primarily from East Texas, were obtained from Angelo State University Natural History Collections, Texas A\&M University Biodiversity Research and Teaching Collections, and The Museum of Texas Tech University ( $n=61$; Suplementary material 1$)$. These specimens were identified to species by the collector or the natural history collection. To determine if traditional or geometric morphometric analyses could confidently differentiate $P$. leucopus and $P$. maniculatus from East Texas, only specimens from which genetic data were obtained (with four exceptions; see below) were included in the analyses.

Laboratory methods. Frozen tissues (stored at $-20^{\circ} \mathrm{C}$ ) or destructive samples of toe clips, skin snips, or rib bones (stored at room temperature) were subjected to molecular assessment. DNA was extracted from frozen tissues using an Omega Bio-Tek E.Z.N.A. Tissue DNA Kit (Omega Bio-Tek, Norcross, Georgia) following manufacturer's instructions. For destructive samples of specimens from natural history collections, all DNA extractions were performed using a QIAmp DNA Micro Kit (QIAGEN Inc., Valencia, California) in a dedicated laboratory for historical samples; this laboratory was free of recent DNA and subjected to rigorous sterilization protocols to prevent contamination. DNA extractions of historical specimens were performed following manufacturer's instructions but also included a 24-h presoak in a 1x phosphate-buffered saline solution.

Because the mitochondrial cytochrome-b (Cytb) gene is one of the most frequently amplified and sequenced mammalian markers and is useful for differentiating Peromyscus species (e. g., Zheng et al. 2003; Dragoo et al. 2006; Lucid and Cook 2007; Gering et al. 2009; Kalkvik et al. 2012; Greenbaum et al. 2017), fragments of this gene were targeted for genetic assessments of specimens included in this study. For DNA extractions of frozen tissues, a 414 base pair (bp) fragment of Cytb was amplified using the primers MVZ04 and MVZ05 (Smith and Patton 1991) following Benedict et al. (2019). Two fragments of Cytb from destructive samples were amplified using primers designed from alignments of $P$. leucopus and $P$. maniculatus. The first fragment amplified a ca. $163 \mathrm{bp}$ fragment using prim- 
ers Pero53F (5'-AATGAATCCTTCATTGATCTCCCCAC- $3^{\prime}$ ) and Pero216R (5'-GTAGTTKACGTCTCGGCAGAT-3') and the second fragment amplified a ca. $130 \mathrm{bp}$ fragment using primers Pero268F (5'-GAGCCTCAATATTCTTYATCTGCTT-3') and Pero402R (5'-GATATTTGTCCTCATGGRAGTACAT-3'). In reference to the full Cytb gene, the 5' nucleotide of Pero53F, Pero216R, Pero268F, and Pero402R occur at base 43, 206, 257 , and 392, respectively (determined via alignments of lab generated sequences to $P$. leucopus GenBank number KY064165 and P. maniculatus GenBank number EF666219). PCR cycling parameters for Cytb fragments from DNA from frozen tissues were initialized with a 5 -minute denaturation step at $95^{\circ} \mathrm{C}, 35$ cycles of $95^{\circ} \mathrm{C}(30 \mathrm{~s}), 52^{\circ} \mathrm{C}(60 \mathrm{~s})$, and $72^{\circ} \mathrm{C}(90 \mathrm{C})$, and a final extension of $72^{\circ} \mathrm{C}$ for 5 min. Cycling parameters were similar for DNA obtained from historical samples except for five additional cycles and an annealing temperature of $45^{\circ} \mathrm{C}$ (or $43^{\circ} \mathrm{C}$ if fragments failed to amplify). All amplified fragments (amplification success was determined via gel electrophoresis) were purified using ExoSAPIT (USB Corporation, Cleveland, Ohio) and sequenced in forward and reverse directions using the primers listed above and $\mathrm{ABI}$ Prism BigDye Terminator cycle sequencing protocols (New Haven, Connecticut) at the DNA Analysis Facility on Science Hill at Yale University. Sequences were edited using Sequencher 4.10 (GeneCodes Corporation, Ann Arbor, Michigan) and compared to published sequences using the National Center for Biotechnology Information Basic Local Alignment Search Tool (BLAST). Top BLAST hits were used to determine species identifications. In our case, given the high prevalence of $P$. leucopus and $P$. maniculatus Cytb sequences on GenBank, there were $>20$ sequences producing significant alignments with $>98 \%$ identity and $>80 \%$ query coverage when we performed our searches. All sequences were deposited to GenBank (Supplementary material 1). In total, 37 specimens of $P$. leucopus from 13 counties (from Denton Co. south to Willacy and Starr Cos.), and 24 specimens of $P$. maniculatus from seven counties (from Denton Co. south to Aransas Co.; Figure 1c; Appendix 1) were genetically identified to species and included in the morphological analyses. Four specimens of $P$. maniculatus failed to amplify for both Cytb fragments (three from Robertson Co. and one from Caldwell Co.); however, successful amplification and sequencing occurred for a minimum of five other specimens from the same or nearby collection locality (Supplementary material 1). We are therefore confident of their species identity and these specimens were retained for morphological analyses. Two of the 37 specimens of $P$. leucopus (TCWC 63781 and 63951) were identified to species by another mitochondrial gene (NADH dehydrogenase 2; from another study conducted by JEL). Laboratory methods and results of BLAST searches were similar to what was described above.

Morphological analysis. Morphological analyses were conducted using both traditional (linear) and 2D geometric morphometric techniques. All genetically identified specimens were adults, as determined by their complete dental eruptions and cheek tooth cusp patterns and wear (Koh and Peterson 1983; Rich et al. 1996). Sixteen standard morphological measurements were taken directly from the specimen tag (external measurements) or using digital calipers: total length (ToL), tail length ( $T L)$, hindfoot length $(\mathrm{HL})$, ear length (EL), depth of braincase (DB), diastema length (DIA), length of incisive foramen (IFL), interorbital constriction (IOC), length of auditory bulla (LAB), mastoid breadth (MB), molar tooth row (MTR), nasal length (NL), occipital-incisor length (OIL), occipital-nasal length (ONL), post-palatal length (PPL), rostral width (RW), and zygomatic breadth (ZB; Figure 2). In some analyses described below, the ratio of tail length to head-body length (TL:TBL) was examined. We recognize that measurements recorded on specimen tags may not always be correct (especially if taken by an inexperienced collector). However, for the purposes of this study, we have accepted them as-is.

Prior to geometric morphometric analyses, specimens were photographed in ventral and lateral cranial views (Figure 2; Appendix 1). Landmark locations were selected, in part, based on previous analyses used to discriminate $P$. leucopus and P. maniculatus (e. g., Myers et al. 1996; Grieco and Rizk 2010; Millien et al. 2017). Both traditional characters and landmark locations were selected to emphasize rostral length and width, tooth arrangement, and zygomatic breadth, regions of cranial morphology known to differ between Peromyscus species (Rich et al. 1996; Millien et al. 2017). All landmarks were placed using tpsDig2 (Rohlf 2001). The number of specimens used in each morphological analysis (i.e., dataset) described below varied as broken specimens or those missing landmark locations were removed from the analyses (traditional morphometrics cranial and external characters: $n=29$ P. leucopus and 20 P. maniculatus; traditional morphometrics cranial characters only: $n=34 P$. leucopus and 22 P. maniculatus; traditional morphometrics external characters only: $n=32$ P. leucopus and 22 P. maniculatus; geometric morphometrics ventral view: $n=35$ P. leucopus and 23 P. maniculatus; geometric morphometrics lateral view: $n=35$ P. leucopus and 18 P. maniculatus; traditional morphometrics cranial and external characters combined with geometric morphometrics ventral and lateral views: $n$ $=27$ P. leucopus and 16 P. maniculatus; Supplementary material 1); analyses including external characters were run using either ToL and TL separately or the TL:TBL ratio.

All traditional morphometric characters were transformed logarithmically to decrease the effect of individual size variation (Gould 1966; dos Reis et al. 1990) and assessed for normality; no extreme outliers were identified and there were no significant departures from a normal distribution for any of the measured characters. Similar to the findings of previous studies (e. g., Kamler et al. 1998; Pergams and Lacy 2008), secondary sexual dimorphism was not found to be associated with any of the cranial traits in either species $(P$ $>0.05$ in all Welch's unpaired $t$-tests of the log-transformed traditional characters); therefore, males and females were pooled in subsequent analyses of traditional morphomet- 
ric characters. In the geometric morphometric analyses, a Procrustes superimposition was applied to remove nonshape related variation associated with location, rotation, and scale on all raw landmark data (Lawing and Polly 2010; Zelditch et al. 2012). Procrustes-corrected data were ordinated using a principal component analysis (PCA). Principal component (PC) scores were extracted from these analyses as independent components of shape variation. As with the traditional morphometric data, secondary sexual dimorphism was not detected in the geometric morphometric datasets as assessed using multivariate analyses of variance (MANOVA) in association with the PC scores of each species (ventral view: $F=0.73, P>0.05$, lateral view: $F=0.99$, $P>0.05)$; therefore, all geometric morphometric analyses were conducted with pooled sexes. Significant size-related allometry was observed using a linear regression on the geometric morphometric datasets (ventral view: $F=3.29, P$ $<0.01$; lateral view: $F=3.50, P<0.01)$. This allometric relationship did not differ significantly between the species as assessed using a multiple linear regression (ventral view: $F$ $=0.58, P>0.05$, lateral view: $F=1.86, P>0.05$; Appendix 2 ); geometric morphometric analyses were conducted using both allometry-minimized and non-allometry-minimized residuals. Both traditional and geometric morphometric analyses were conducted using $\mathrm{R}$ version 3.6.3, with the MASS and geomorph packages (Venables and Ripley 2002; Adams et al. 2020; R Core Team 2020).

Welch's unpaired $t$-tests were performed to assess differentiation between species for each individual traditional morphometric character; Bonferroni corrections were included to account for the number of individual tests. PCAs were performed on the log-transformed traditional morphometric variables using a covariance matrix (the scales of the variables are standardized after log-transformation; Croux and Haesbroek 2000). MANOVAs were conducted on both traditional and geometric morphometric datasets using PC scores to detect differentiation between species and analyses of variance (ANOVAs) were used to detect the specific PCs that differed between species. Discriminant function analyses (DFAs) were performed to determine if specimens could be separated based on the a priori hypothesis of group membership to genetically identified species. Leave-one-out cross-validation linear discriminant function analyses (DFA-CVs) also were performed to determine if $a$ priori group membership could be appropriately predicted. In these analyses, individual specimens were assessed in an iterative process, removing each specimen from the training dataset to estimate the likelihood that it is included within either $P$. leucopus or $P$. maniculatus based on its morphology. Both DFAs and DFA-CVs were performed on all datasets (with allometry-minimized and non-allometryminimized residuals for the ventral and lateral cranial views) as well as combined geometric and traditional morphometric datasets. For analyses including linear measurements from the traditional morphometric datasets, both the PCs of these linear measurements (as in geometric morphometrics) as well as the log transformed data were examined. For all DFAs and DFA-CVs, specimens were assigned posterior probabilities (pp) of membership to P. leucopus or P. maniculatus based on Mahalanobis distance.

Multiple logistic regressions were conducted to examine the relationship between specimen misidentification and morphology (for both traditional morphometric traits and PC scores extracted from geometric morphometric analyses). Specimen misidentification was tabulated for each specimen as a binary 'yes' or 'no' based on the specimen's genetic identification and the identification originally assigned by the collector or natural history collection.

To further examine the distribution of $P$. maniculatus in Texas, data were downloaded from VertNet (accessed 17 January 2021) for all specimens with the county of collection and external measurement information $(n=386)$. These were then further classified as either likely correct species identification (multiple localities of multiple individuals for
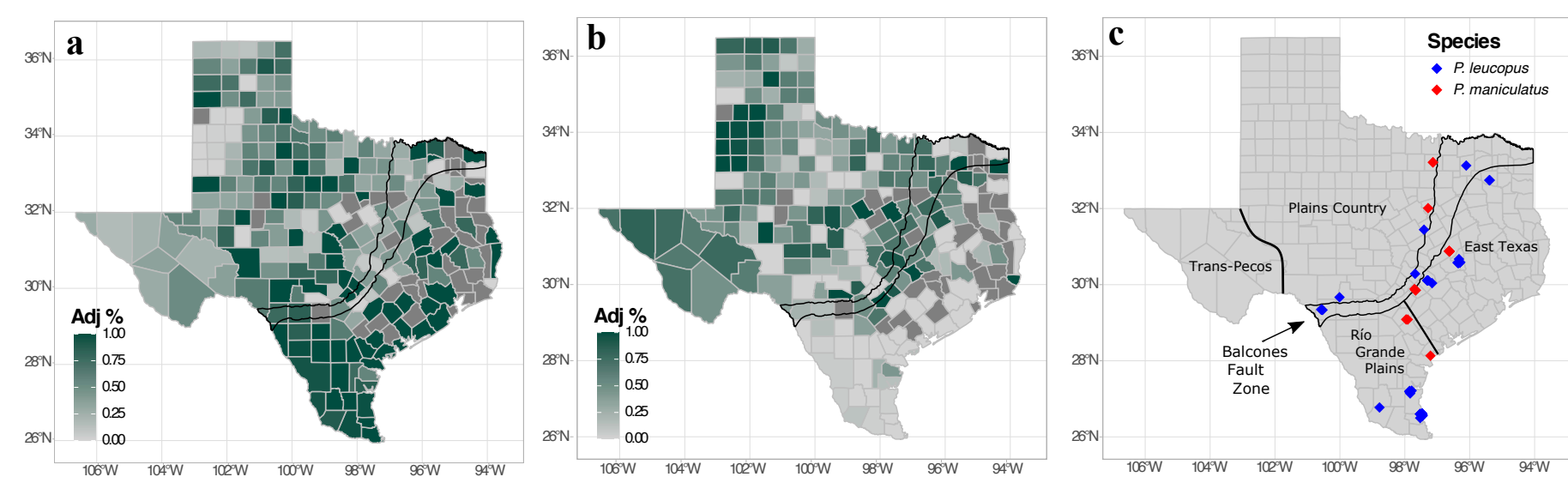

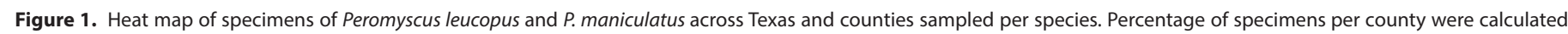

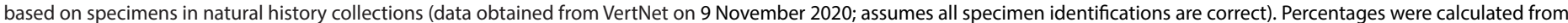

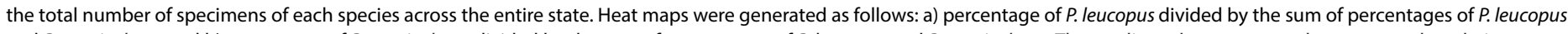

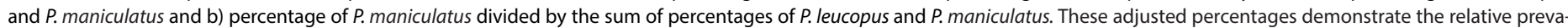

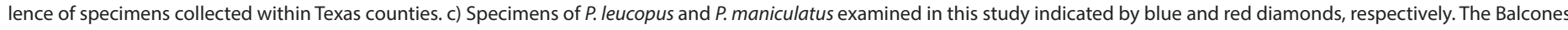
fault zone is indicated with a black border. 

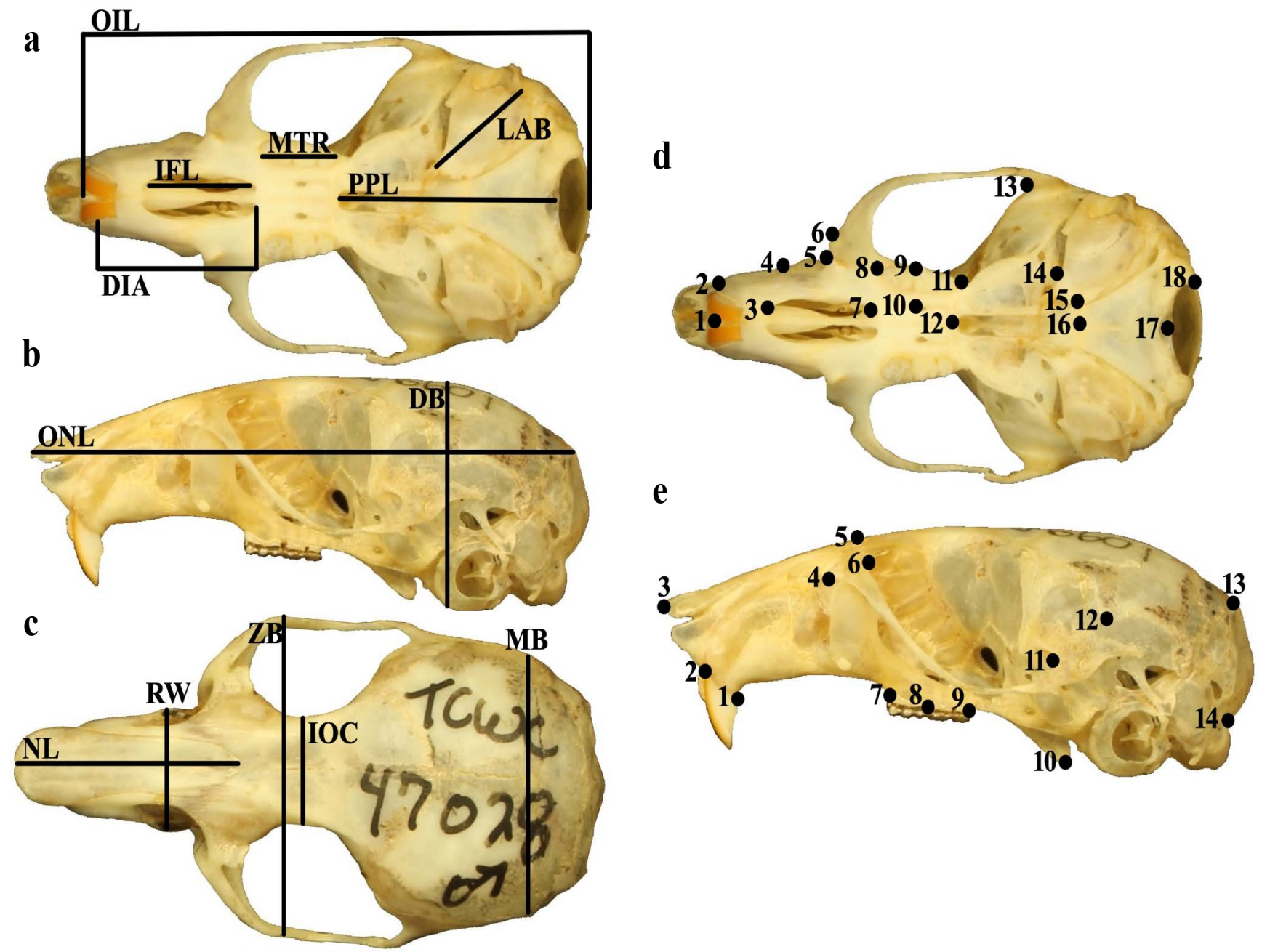

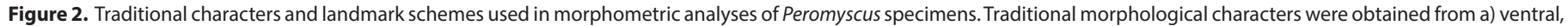

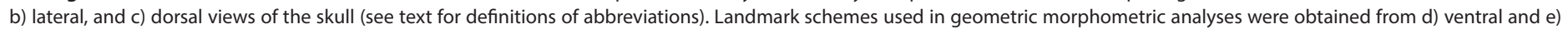
lateral views of the skull (see text for anatomical definitions of landmarks).

that county) or "suspect" (only a single locality, often with only a single individual, for that county). This "suspect" classification based on county occurrence was considered reasonable due to the rather constant geographic area of counties in eastern Texas, forming a nearly uniform grid: the 126 counties of eastern Texas (as defined here; Figure 1) average $2,302 \mathrm{~km}^{2}$, or about $50 \mathrm{~km}$ on a side, and a single county record could reasonably be considered of suspect identification. Suspect specimens were included as unassigned specimens in a DFA (SYSTAT 7.0, Wilkinson 1997) based on external measurements (ToL, TL, HL, and EL) with the genetically identified reference samples. Suspect specimens were assigned posterior probabilities (pp) of membership to the two reference groups based on Mahalanobis distance and grouped for comparison with those reference samples into geographic groups representing $P$. leucopus and the Texas subspecies of $P$. maniculatus: $P$. $m$. pallescens in East Texas, P. m. blandus in West and South Texas, and P. $m$. luteus in the Texas Panhandle. Specimens were assigned to subspecies of $P$. maniculatus based on geographic distribution, and differences among these taxa and the genetically identified reference groups were assessed using Tukey's honestly significant difference post hoc tests.

\section{Results}

Traditional morphometrics. Welch's Two-Sample $t$-tests indicated a significant difference between $P$. leucopus and $P$. maniculatus in many traditional linear characters. All cranial and external traits except length of auditory bulla (LAB) and length of incisive foramen (IFL) were significantly different between species $(P<0.001$; Figure 3; Appendix 3). The first principal component (PC1) associated with the traditional characters accounted for $60.81 \%$ of the total variation, all coefficients had the same sign, and occipital-nasal length (ONL) and occipital-incisor length (OIL) had the highest loadings (eigenvalue of PC1 = 9.73; Figure 4; Appendix 4). PC2 of the traditional morphometric dataset accounted for $9.75 \%$ of the total variation and was primarily associated with length of auditory bulla (LAB) and length of incisive foramen (IFL; Figure 4; Appendix 4). MANOVA results indicated that PC scores of $P$. leucopus and $P$. maniculatus were significantly different $(P<0.001)$, including a significant difference between species associated with PC1 $(P<0.001)$ and PC2 $(P<0.05)$.

Geometric morphometrics.-Geometric morphometric analyses also detected a significant difference between $P$. 
leucopus and $P$. maniculatus based on cranial size and certain axes of morphology. In the ventral view, PC1 accounted for $18.46 \%$ of the overall variation in the allometry-minimized dataset and was primarily related to the relative skull length and cheek-tooth arrangement, whereas PC2 accounted for $13.34 \%$ of the variation and was primarily associated with the relative rostral length and skull width (Figure 4). In the lateral view, PC1 accounted for $27.94 \%$ of the variation in the allometry-minimized dataset and was associated with cranial width and depth and PC2 accounted for $17.69 \%$ of the variation and was associated with skull length and postdental cranial width (Figure 4). Results were similar for analyses of non-allometry-minimized datasets (data available upon request). MANOVAs associated with the allometryminimized ventral- and lateral view analyses failed to detect a significant overall morphological difference between the species $(P>0.05)$, although this relationship was significant with the non-allometry-minimized cranial views $(P<0.0001$; Appendix 5). ANOVAs of individual allometry-minimized PCs detected several axes of morphological differentiation between the species, including PC1 of the ventral view $(P$ $<0.01$ ) and PC2 and PC4 of the lateral view (both $P<0.05$ ). Results were similar for ANOVAs of non-allometry-minimized datasets (data available upon request).

Specimen misidentification and distribution of P. maniculatus in Texas.-Genetic analyses revealed that 21 of 61 (34.43\%) specimens in our dataset, all P. leucopus, had previously been misidentified; 14 of these misidenti- fied specimens are from east of the Balcones Escarpment (Appendix 1). Discriminant function analysis (DFA) on various suites of morphological characters correctly classified (posterior probability, or $\mathrm{pp},=1$ ) the majority of specimens of $P$. leucopus and $P$. maniculatus to species, regardless of the dataset analyzed (e. g., cranial characters only, cranial and external characters, and combined datasets; Table 1). For DFAs of traditional morphological characters, results were similar whether PCs or log-transformed data were used, or if total length (ToL) and tail length (TL) were analyzed separately or as part of the tail length to headto-body length ratio (Table 1). ONL, OIL, and ToL tended to have the highest factor loadings. In DFAs of exclusively external characters, TL had the highest factor loadings and no specimens were misclassified. However, in analyses of log-transformed external data, there was low certainty in the classification of three specimens of $P$. maniculatus (pp $=0.54$ for TCWC 46975, 0.61 for TCWC 46976, and 0.66 for 46994; Appendix 1). Similarly, DFA of the PCs of the external data resulted in four specimens of $P$. maniculatus misclassified (TCWC 46974, 46975, 46994, and 46998), and there was low certainty of classification for four specimens of $P$. leucopus ( $p p=0.51$ for TCWC 63240, 0.67 for TCWC 63355, 0.63 for TCWC 63781, and 0.65 for TCWC 64157) and one specimen of $P$. maniculatus ( 0.72 for TCWC 46976). DFA using the non-allometry-minimized residuals of the combined ventral and lateral cranial views resulted in high confidence of classification (pp > 0.80) for both species with TCWC 56617

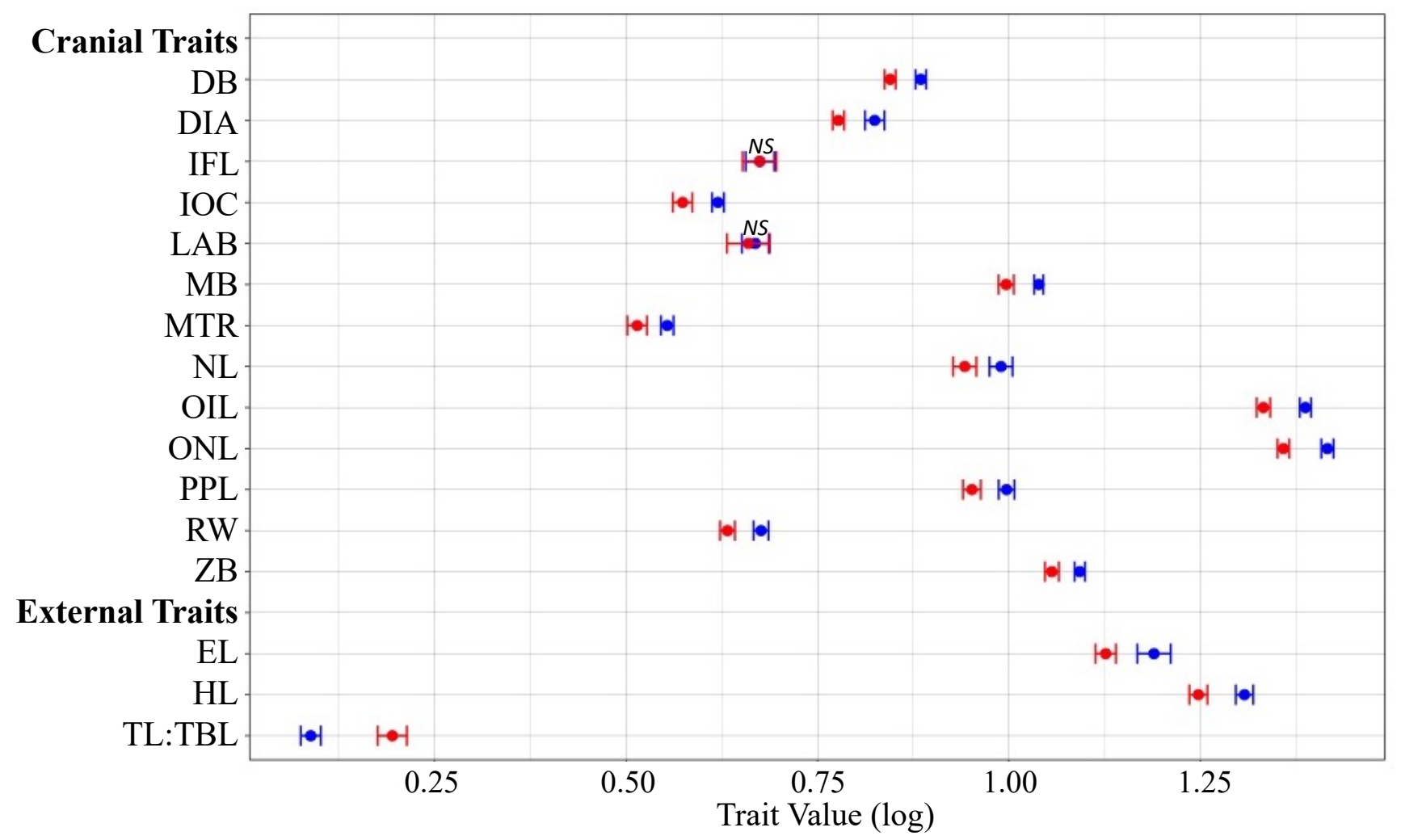

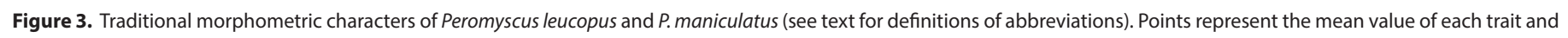

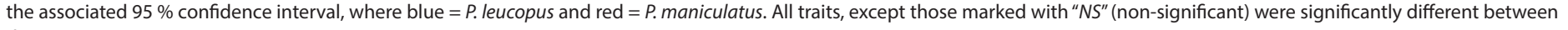
the two species. 


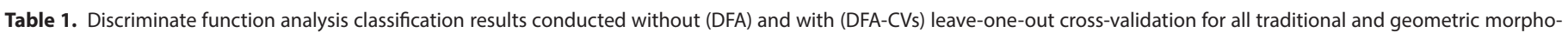
metrics analyses and datasets. Type of data examined for each morphometric dataset is indicated.

DFA \% Correct

DFA-CVs \% Correct

Morphometric Analysis

Dataset

P. leucopus

P. maniculatus

P. leucopus

P. maniculatus

\begin{tabular}{|c|c|c|c|c|c|}
\hline \multicolumn{6}{|c|}{ Log-Transformed Traditional Data } \\
\hline Traditional & Cranial \& External ${ }^{1}$ & 100 & 100 & 100 & 95 \\
\hline Traditional & External only ${ }^{1}$ & 100 & 86.36 & 96.88 & 77.27 \\
\hline Traditional & Cranial only & 100 & 100 & 100 & 90.91 \\
\hline \multicolumn{6}{|l|}{ Principal Components } \\
\hline Traditional & Cranial \& External ${ }^{1}$ & 100 & 100 & 100 & 100 \\
\hline Traditional & External only & 87.50 & 77.27 & 84.38 & 72.73 \\
\hline Traditional & Cranial only & 100 & 100 & 97.06 & 95.45 \\
\hline Geometric $^{2}$ & Ventral \& Lateral & 94.12 & 83.33 & 94.12 & 83.33 \\
\hline Geometric $^{3}$ & Ventral \& Lateral & 73.53 & 27.78 & 73.53 & 27.78 \\
\hline Geometric $^{2} \&$ Traditional & Ventral \& Lateral, Cranial \& External ${ }^{1}$ & 100 & 100 & 100 & 100 \\
\hline Geometric $^{3} \&$ Traditional & Ventral \& Lateral, Cranial \& External ${ }^{1}$ & 100 & 100 & 100 & 100 \\
\hline \multicolumn{6}{|c|}{ Log-Transformed Traditional Data \& Geometric Morphometric Principal Components } \\
\hline Geometric $^{2} \&$ Traditional & Ventral \& Lateral, Cranial \& External ${ }^{1}$ & 100 & 100 & 100 & 100 \\
\hline Geometric $^{3}$ \& Traditional & Ventral \& Lateral, Cranial \& External ${ }^{1}$ & 100 & 100 & 100 & 100 \\
\hline
\end{tabular}

'Results were similar regardless of if the total length and tail length external characters were examined separately, or included as a ratio of tail length to head-body length. ${ }^{2}$ Non-allometry-minimized residuals.

${ }^{3}$ Allometry-minimized residuals.

a

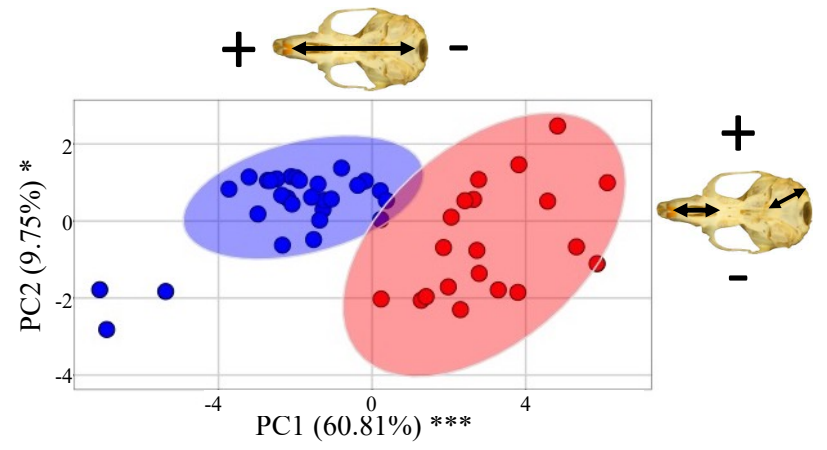

c
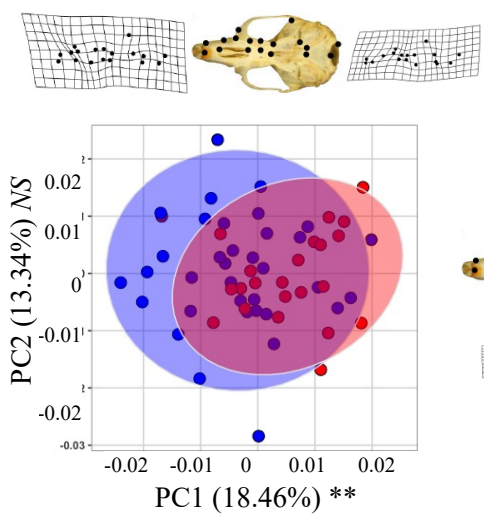

b

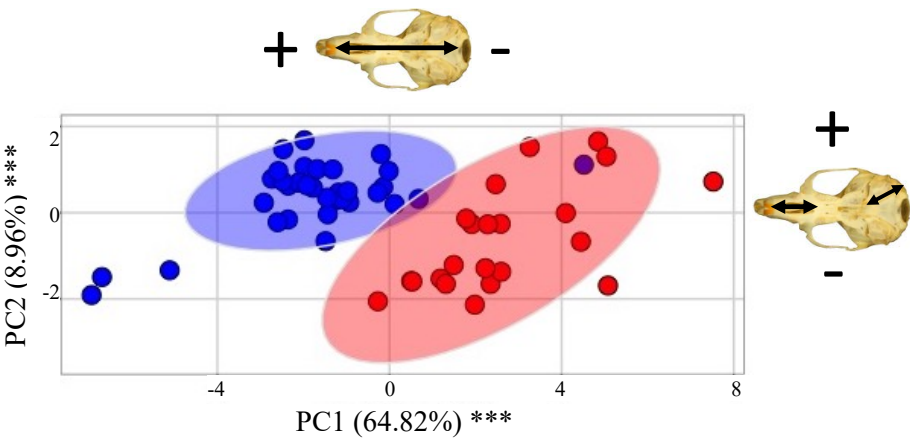

d

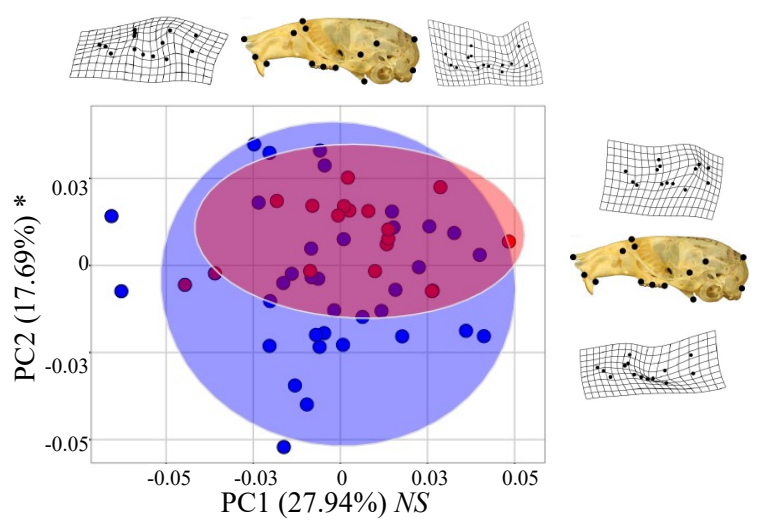

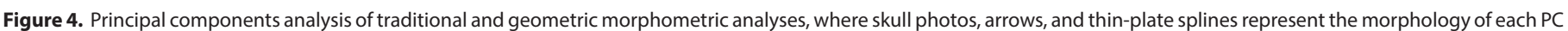

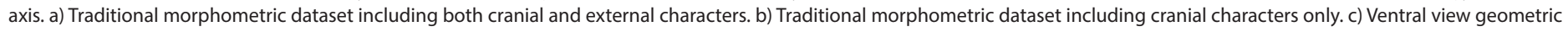

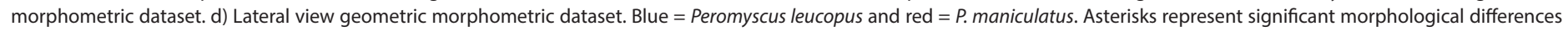

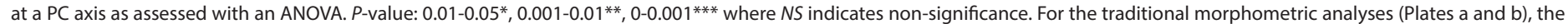

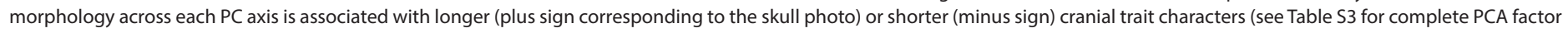

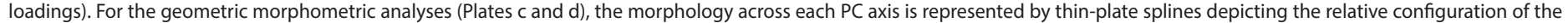
skull morphology at the extremes of each PC axis. 
misclassified as a P. maniculatus and TCWC 46972 misclassified as a P. leucopus; however, all specimens were correctly classified with the inclusion of traditional morphological characters (Table 1). By far, the worst-performing dataset was that using allometry-minimized residuals of the combined ventral and cranial views (although all specimens were again correctly classified with the inclusion of traditional morphological characters). Results for the crossvalidation linear discriminant function analyses (DFA-CVs) were similar to those of the DFAs, although sometimes with increased rates of misclassification (Table 1). When geometric and traditional morphometric data were combined in singular DFA and DFA-CV analyses, ventral and lateral cranial views had the highest factor loadings.

Multiple logistic regressions did not detect a significant association between species misidentification and morphology in either the traditional or geometric morphometric analyses (including both allometry-minimized and $\mathrm{a}$

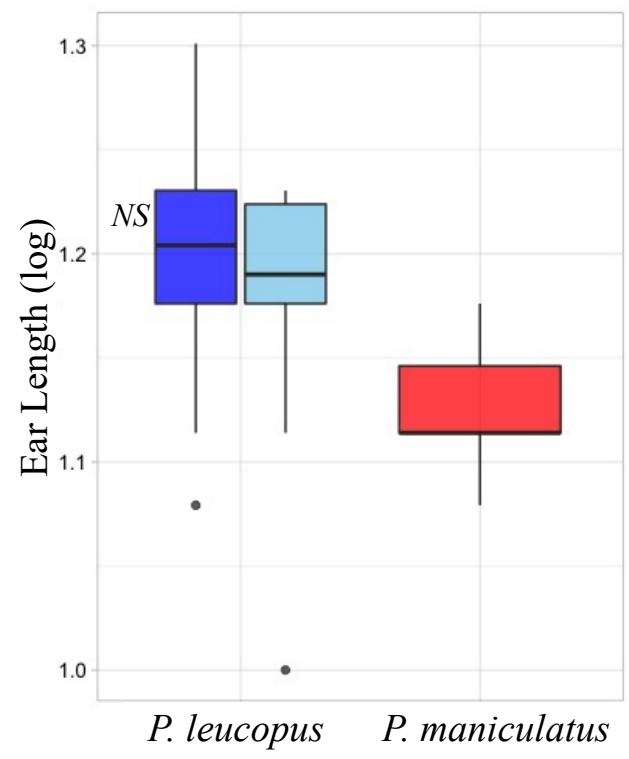

b

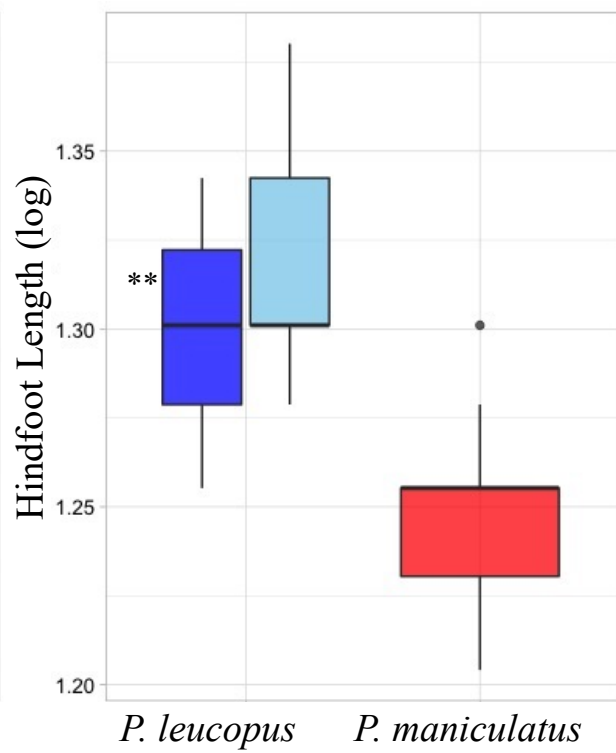

c

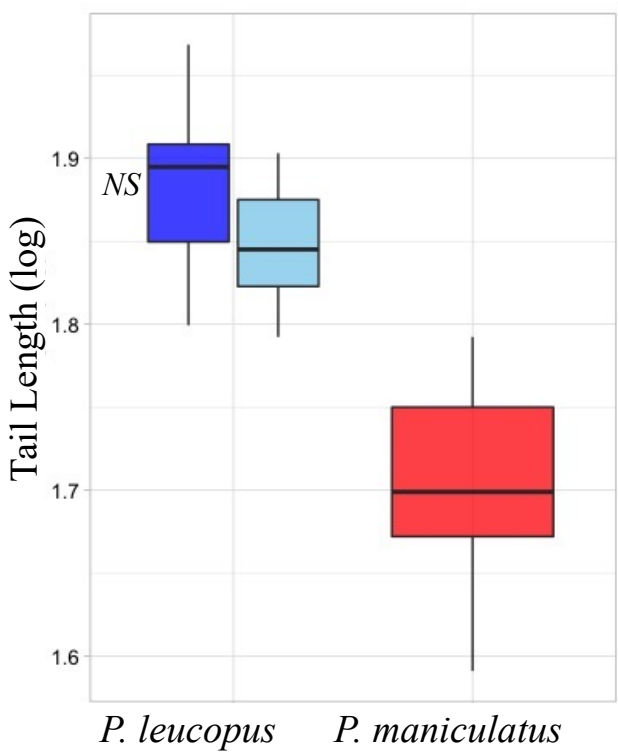

d

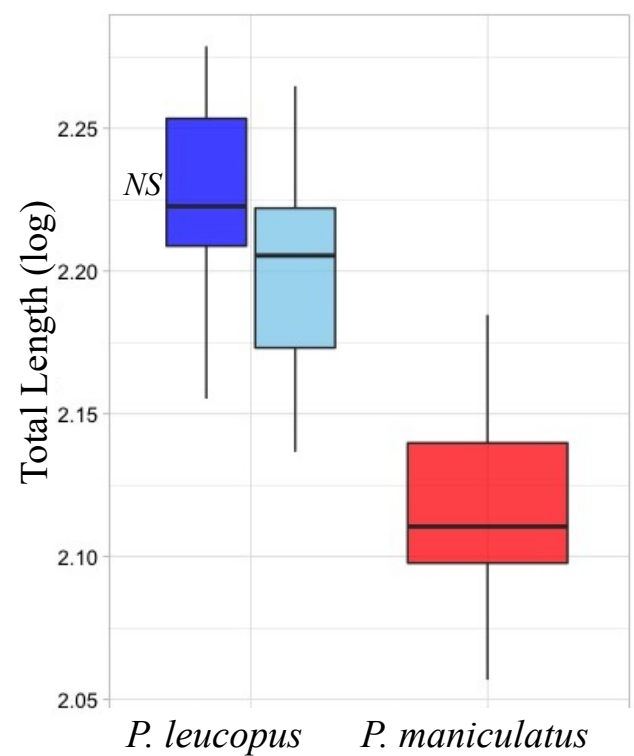

e

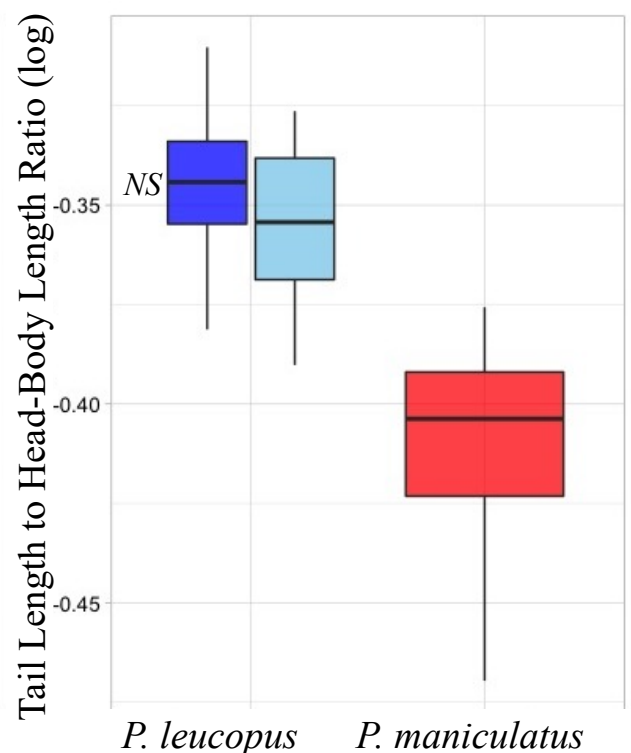

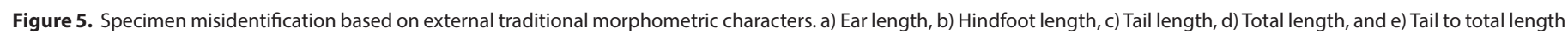

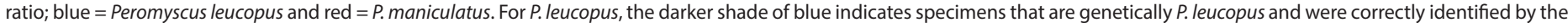

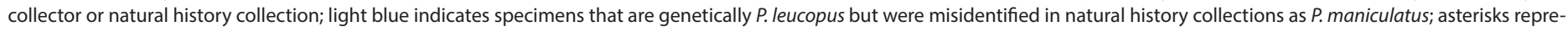

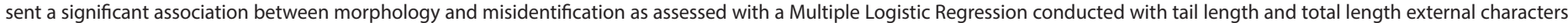

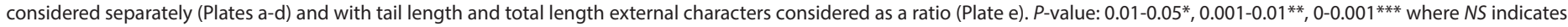
non-significance. 
non-minimized datasets). However, when conducted using exclusively traditional external morphometric characters (ToL, TL, HL, EL, and TL:TBL), multiple logistic regression detected a significant relationship between species misidentification and hindfoot length $(P<0.01)$, where specimens of $P$. leucopus with the longest hindfoot length were more likely to be misidentified (Figure 5).

For the additional specimens downloaded from VertNet with county of collection and external measurement information, of the 56 counties of eastern Texas from which $P$. maniculatus has been recorded, 29 were represented by a single locality, and 17 of those 29 were represented by a single specimen. Twelve of these single sample, single site records are from south or considerably east of the fault zone indicating that $P$. maniculatus may not be common in this region of Texas. Four taxonomic groups were compared in the DFA based on external measurements only (Figure 6): P. m. blandus $(n=99), P . m$. luteus $(n=119)$, and the reference groups of $P$. m. pallescens $(n=22)$ and P. leucopus $(n=32)$. All taxonomic groups were significantly different $(P<0.01)$ from one-another with the exception of $P$. m. blandus and $P$. leucopus $(P=0.687)$. Specimens of suspect identification as $P$. m. pallescens $(n=30)$ from 16 counties in East Texas were assigned to either $P$. maniculatus ( $n=20$ from eight counties) or $P$. leucopus ( $n=10$ from eight counties) with a posterior probability (pp) of $\geq 0.75$. Specimens with suspect identification as P. m. blandus $(n=17)$ from six counties in the Río Grande Plains were assigned to P. leucopus (pp $\geq 0.90$ ). However, it is not possible to distinguish this subspecies from $P$. leucopus based on external measurements alone, and these localities remain as undetermined species (Figure 6). An additional 13 specimens from four counties were assigned with a lower pp and were excluded from further consideration.

\section{Discussion}

This study resulted in several main findings: 1) genetically identified specimens of $P$. leucopus and $P$. maniculatus from east of the Balcones fault zone in Texas can be differentiated morphologically based on size; 2 ) both traditional and geometric morphometric techniques can be used to differentiate these species; 3 ) many of the specimens of $P$. leucopus used in this study were originally misidentified as P. maniculatus; and 4) P. maniculatus appears to be rare in East Texas.

Morphological species differentiation. Results from this study generally support that analysis of a suite of morphological characters can successfully differentiate $P$. leucopus and $P$. maniculatus (Figure 4; Table 1). Although multiple traditional morphological characters can be used to differentiate P. leucopus and P. maniculatus (Figure 3), it is unlikely that these two species can be consistently differentiated based on any one morphological character alone, similar to findings from previous studies (e. g., Choate 1973; Choate et al. 1979; Stromberg 1979; Feldhamer et al. 1983; Thompson and Conley 1983; Rich et al. 1996; Kamler et al. 1998;
Lindquist et al. 2003; Reed et al. 2004; Stephens et al. 2014; Millien et al. 2017). For example, although length of incisive foramen (IFL) and length of auditory bulla (LAB) were not significantly different between $P$. leucopus and $P$. maniculatus when assessed individually in the traditional morphometric analyses (Figure 3 ), these two characters were significant $(P<0.05)$ drivers of PC2, which differed significantly $(P<0.05)$ between the species (Figure 4$)$.

Field researchers often rely on individual external characters such as hindfoot length, ear length, tail length, or the ratio tail length to head-body length for identification of $P$. leucopus and $P$. maniculatus. The utility of these characters, however, often varies with geography. Some studies have used external characters to successfully differentiate $P$. leucopus and P. maniculatus (e. g., Kamler et al. 1998; Ridenhour and Cramer 2015) whereas other studies were not successful (e. g., Feldhamer et al. 1983; Stromberg 1979; Palas et al. 1992; Stephens et al. 2014). Given the variation in the utility of external characters to differentiate $P$. leucopus and $P$. maniculatus, reliance on these characters may be associated with species misidentification (see below). Although this study shows genetically-identified $P$. leucopus and $P$. maniculatus can be correctly classified with greater than 80 $\%$ confidence when exclusively using external characters, low certainty of classification and misclassification of individual specimens still occurred (Table 1). This finding provides additional support for caution when using exclusively external characters to differentiate these two morphologically similar species.

Size appears to be especially important when differentiating $P$. leucopus and P. maniculatus in East Texas; there is minimal overlap of these species in principal component morphospace (Figures 4a and 4b) and all or nearly-all specimens were correctly classified in discriminant function analyses when including datasets that accounted for size (Table 1). Examination of centroid sizes for both ventral and lateral views from geometric morphometrics (the square root of the sum of squared distances between each landmark and the geometric center of the landmark scheme; Zelditch et al. 2012), which primarily examines size, revealed clear separation between $P$. leucopus and $P$. maniculatus (Appendix 6 ). However, when size is removed from principal component analyses, there is substantially more species overlap in morphospace. This can be seen when examining PC2 and PC3 of the traditional morphological characters (Appendix 7) and PC1 and PC2 of the geometric morphometric datasets (Figures $4 \mathrm{c}$ and $4 \mathrm{~d}$ ). Additionally, species misclassification when analyzing allometry-minimized residuals (which reduces the effect of size relative to shape) of ventral and lateral cranial data was substantially higher than when analyzing non-allometry minimized residuals (Table 1). Shape can still be used to differentiate $P$. leucopus and $P$. maniculatus (DFAs as well as PCs of the ventral and lateral views of the skull having the highest factor loadings when geometric and traditional morphometric data were combined in DFA and DFA-CV analyses), but it appears to be 
less important than size in differentiating these two species in this region. Given that $P$. leucopus and $P$. maniculatus last shared a common ancestor approximately 2.5 million years ago (Platt et al. 2015; Bradley et al. 2019) and are separated by at least eight speciation events (Greenbaum et al. 2019), the overall morphological similarity in shape observed between these two species is consistent with a hypothesis of remarkable convergent evolution between these two species. Mitochondrial DNA data from P. maniculatus sensu lato has been hypothesized to represent multiple, cryptic species across its geographic range (reviewed in Bradley et al. 2019 and Greenbaum et al. 2019) and it is unknown if there are reliable and consistent morphological differences among these putative species.

Traditional and geometric morphometrics. Both traditional and geometric morphometric techniques can be used to differentiate these species, primarily based on size as described above. Traditional morphometrics are by far the more common methodology used to morphologically differentiate mammalian species and continue to be a reliable and efficient way to examine morphological differentiation. Geometric morphometric techniques are primarily used to examine the inter-relationship across multiple landmark locations, reducing the influence of rotation, location, and scale to explore shape exclusive of size (Lawing and Polly 2010; Zelditch et al. 2012), thereby offering a novel way to examine morphological shape. In addition to our study, geometric morphometric analyses of other cranial and mandibular views have been useful in differentiating $P$. leucopus and $P$. maniculatus in other geographic regions (e.g., width of skulls and size of braincases in Berens 2015; length and width of the rostrum and the position of the anterior margin of the tooth row; Millien et al. 2017) and with other rodent species (e. g., expanded crania in Camargo et al. 2019; thickness of mandibles and shapes of mandibular processes in Rowsey et al. 2019). Future workers attempting to differentiate $P$. leucopus and $P$. maniculatus across their geographic range therefore have options regarding types of data to collect and analyses to perform.

Specimen misidentification and P. maniculatus distribution in Texas. Over a third of the specimens examined in this study initially were misidentified. This is alarming given the use of Peromyscus specimens in a wide variety of ecological and evolutionary studies as well as the economical and medical importance of $P$. leucopus and $P$. maniculatus as reservoirs for disease-causing pathogens. Some of these misidentifications are apparently the result of over-reliance on certain traits, such hindfoot length (Figure 5). Specimens of $P$. leucopus with relatively long hindfoot measurements were more likely to be misidentified, a surprising result given that $P$. maniculatus has comparatively shorter hindfeet. These results imply that specimens measured incorrectly or with unusual body proportions may be more likely to be misidentified.

This study resulted in the reassignment of specimens of $P$. maniculatus to $P$. leucopus from localities in 19 Texas counties, five of which were among the few supposed records of $P$. maniculatus located east of the Balcones fault zone (Figure 6). These corrections were based on either molecu-

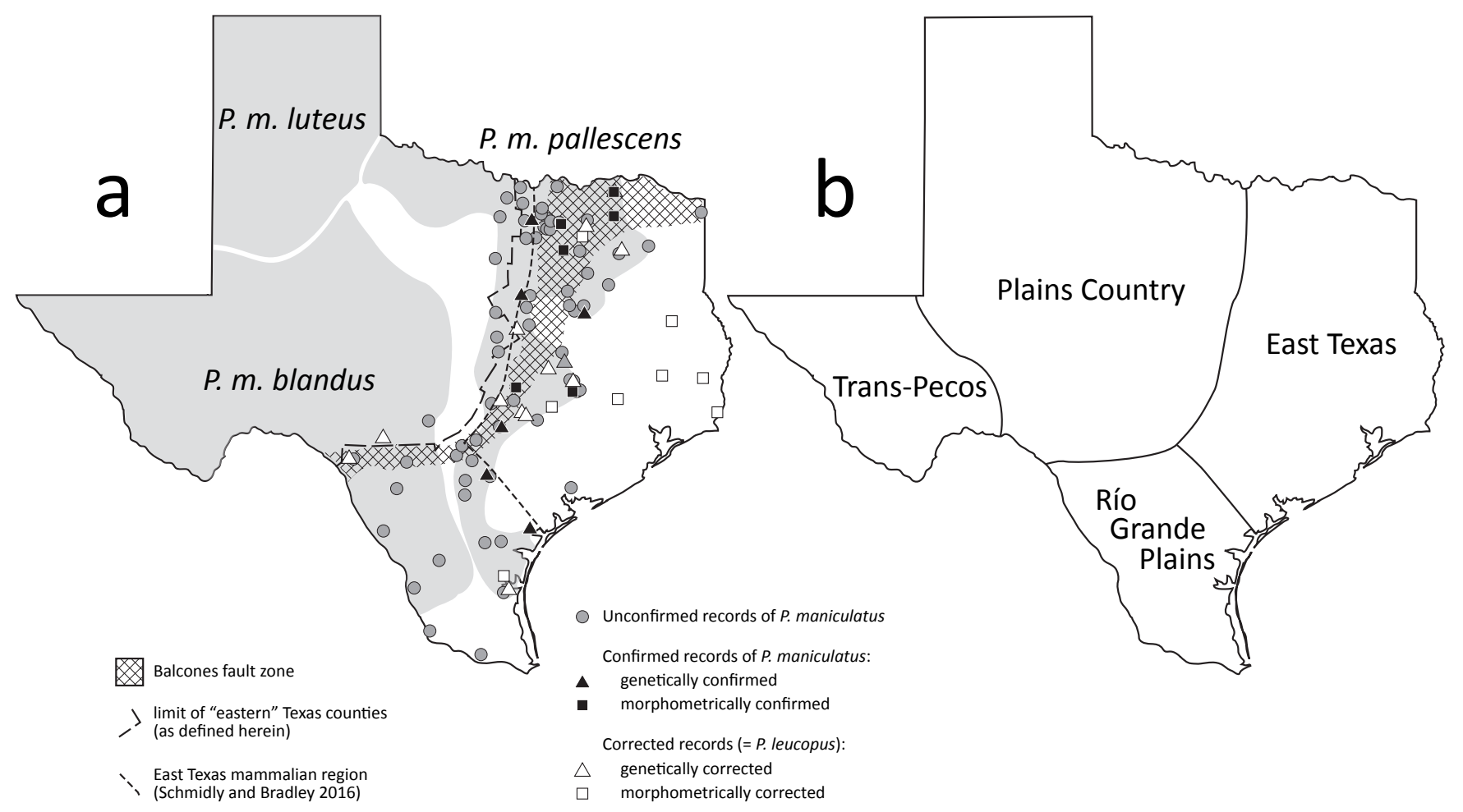

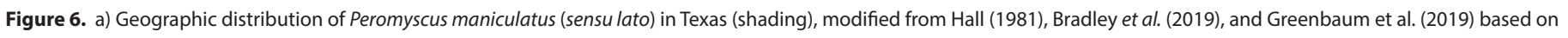
VertNet localities. b) Mammalian regions of Texas (Schmidly and Bradley 2016). 
lar sequences (12 localities in 11 counties; Supplementary material 1) or the significantly larger external measurements observed in VertNet specimens from $P$. leucopus versus $P$. maniculatus (8 localities in 8 counties; Kleberg, Lee, Montgomery, Nagadoches, Orange, Polk, Rockwall, and Tyler Cos.). Because only external characters from VertNet were examined, juvenile $P$. leucopus (being smaller) might be mistaken for $P$. maniculatus, and localities that could not be assigned to species may represent a mixture of juvenile and adult $P$. leucopus, mixtures of the two species, or simple errors in measurements. Additional research should examine skull and dental morphology of these specimens to determine appropriate age classes such that external characters can be more confidently used in future analyses (but see results above recommending use of a suite of morphological characters to differentiate $P$. leucopus and $P$. maniculatus).

It is clear that $P$. maniculatus is far less common east of the Balcones fault zone than was previously thought (Figure 6). Museum records previously indicated that $P$. maniculatus occurred in 21 counties east of the Balcones fault zone; records from 10 of those 21 counties have been reidentified as P. leucopus, four based on genetics (Bastrop, Brazos, Kenedy, and Milam Cos.) and six based on external morphology (Kleberg, Montgomery, Nagadoches, Orange, Polk, and Tyler Cos.). In addition to the remaining unconfirmed species records from 11 counties east of the fault zone, there are several specimens from localities from southern Texas (Figure 6) that may eventually be determined to be either P. leucopus or P. maniculatus. Thus, the Balcones fault zone may limit the distribution of $P$. maniculatus in Texas, as it does for many other taxa and that different climates, flora, and fauna across the four major regions in Texas (TransPecos, Plains Country, East Texas, and Rio Grande Plains), and may additionally delimit the distribution of cryptic species within P. maniculatus (Bradley et al. 2019; Greenbaum et al. 2017, 2019). Future research with increased sampling is needed to determine the geographic range of "P. maniculatus" species in Texas.

The level of specimen misidentification observed herein is also of concern to natural history collections and researchers using specimens from these collections; large numbers of specimens in collections may be misidentified. Researchers, curators, and collections managers could use the same morphometric methods as described in this study to verify the species identification. Care should be taken, however, to recognize that $P$. leucopus and $P$. maniculatus are morphologically variable across their geographic range and the methodologies used in this study may not result in similar findings if used in different geographic areas even though use of a suite of morphological characters has repeatedly been shown to accurately differentiate these species (e. g., this study; Choate 1973; Choate et al. 1979; Stromberg 1979; Feldhamer et al. 1983; Thompson and Conley 1983; Rich et al. 1996; Kamler et al. 1998; Lindquist et al. 2003; Reed et al. 2004; Stephens et al. 2014; Millien et al. 2017). Researchers trying to assess identification of unknown specimens will need to adjust their analyses accordingly (e. g., use a base dataset including geneticallyknown specimens such as used in this study and include "unknown" specimens in PCAs and DFAs). Field ecologists and others working with specimens of Peromyscus in the field should consider recording additional data at the site of capture, such as external measurements in the field as well as habitat of collection, because $P$. leucopus and $P$. maniculatus are known to differ in their habitat preferences. To be truly confident in species identifications of $P$. leucopus and $P$. maniculatus in East Texas and possibly throughout their range, genetic or molecular tools are likely to be the most accurate methodology.

Determination of the distribution and relationships of the taxa within P. maniculatus sensu lato in Texas will depend on additional genetic sampling and responsible collecting efforts, possibly via novel collaborations with field courses and wildlife agencies (McLean et al. 2016; Cook and Light 2019; Miller et al. 2020). Newly collected specimens accessioned into natural history collections are vital to the future of organism-based research. These specimens can be invaluable for a variety of disease ecology, evolutionary, and distributional studies, especially those examining fairly common species such as $P$. leucopus and $P$. maniculatus in eastern Texas.

\section{Acknowledgments}

This work could not have been completed without the assistance of natural history collections and their curators and collections managers. Thank you to the American Museum of Natural History, Angelo State University Natural History Collections, Texas A\&M University Biodiversity Research and Teaching Collections, and Museum of Texas Tech University for providing specimens for this research. S. Jansa, N. Hamilton, members of the Light Lab, and three anonymous reviewers provided helpful comments on earlier drafts of this manuscript and A. Lira Olguín provided a translation of the abstract and D. Dillard uploaded cranial images to the Texas A\&M OakTrust image repository. This is publication 1641 of the Biodiversity Research and Teaching Collections at Texas A\&M University.

Dedication. The authors dedicate this manuscript in honor of David J. Schmidly in recognition of his lifelong commitment and prolific contributions to the science and history of mammalogy. To one of us (IFG), David Schmidly has been a mentor, role model, academic and field colleague, NSF co-investigator and friend since his undergraduate days. David remains an inspiration to all of us. We gratefully thank Robert and Lisa Bradley for the invitation to participate in this festschrift honoring Professor Schmidly.

\section{Literature Cited}

Adams, D. C., M. L. Collyer, and A. Kaliontzopoulou. 2020. Geomorph: Software for geometric morphometric analyses. R package version 3.2.1. https://cran.r-project.org/ package=geomorph. 
Adams, D. C., F. J. Rohlf, AND D. E. Slice. 2004. Geometric morphometrics: ten years of progress following the 'revolution'. Italian Journal of Zoology 71:5-16.

Aquadro, C. F., ANd J. C. Patton. 1980. Salivary amylase variation in Peromyscus: use in species identification. Journal of Mammalogy 61:703-707.

Bedford, N. L., ANd H. E. Hoekstra. 2015. The natural history of model organisms: Peromyscus mice as a model for studying natural variation. Elife 4:e06813.

Benedict, B. D., A. A. Castellanos, and J. E. Light. 2019. Phylogeographic assessment of the Heermann's kangaroo rat (Dipodomys heermanni). Journal of Mammalogy 100:72-91.

Berens, J. D. 2015. Morphological differences and diversity of small mammal species. Master's Thesis. Department of Environmental and Conservation Sciences, North Dakota State University, U.S.A.

Berl, J. L., E. A. Flaherty, B. J. Danielson, K. F. Kellner, and R. K. SWIHART. 2017. Winter ecology of prairie deer mice (Peromyscus maniculatus bairdii) in cultivated habitats: Implications for agricultural ecosystem services. Agriculture, Ecosystems \& Environment 249:130-136.

Bradley, R. D., J. Q. Frances. R. N. Platt II, T. J. Soniat, D. AlVAREZ, AND L. L. Lindsey. 2019. Mitochondrial DNA sequence data indicate evidence for multiple species within Peromyscus maniculatus. Special Publications of the Museum of Texas Tech University 70:1-59.

Breno, M., H. Leirs, And S. Van Dongen. 2011. Traditional and geometric morphometrics for studying skull morphology during grown in Mastomys natalensis (Rodentia: Muridae). Journal of Mammalogy 92:1395-1406.

Bruseo, J. A., S. H. Vessey, and J. S. Graham. 1999. Discrimination between Peromyscus leucopus noveboracensis and Peromyscus maniculatus nubiterrae in the field. Acta Theriologica 44:151-160.

Camargo, N. F., L. F. Machado, A. F. Mendonca, and E. M. Vieira. 2019. Cranial shape predicts arboreal activity in Sigmodontinae rodents. Journal of Zoology 308:128-138.

Childs, J. E., T. G. Ksiazek, C. F. Spiropoulou, J. W. Krebs, S. Morzunov, G. O. Maupin, K. L. Gage, P. E Rollin, J. Sarisky, R. E Enscore, And J. K. Frey. 1994. Serologic and genetic identification of Peromyscus maniculatus as the primary rodent reservoir for a new hantavirus in the southwestern United States. Journal of Infectious Diseases 169:1271-1280.

Choate, J. R. 1973. Identification and recent distribution of white-footed mice (Peromyscus) in New England. Journal of Mammalogy 54:41-49.

Choate, J. R., R.C. Dowler, and J. E. Kraus. 1979. Mensural Discrimination between Peromyscus leucopus and P. maniculatus (Rodentia) in Kansas. Southwestern Association of Naturalists Stable 24:249-258.

Cook, J. A., AND J. E. Light. 2019. The emerging role of mammal collections in $21^{\text {st }}$ century mammalogy. Journal of Mammalogy 100:733-750.

Croux, C., and G. Haesbroeck. 2000. Principal component analysis based on robust estimators of the covariance or correlation matrix: influence functions and efficiencies. Biometrika 87:603-618.

Dalquest, W. W., and F. B. Stangl, JR. 1983. Identification of seven species of Peromyscus from Trans-Pecos Texas by char- acters of the lower jaw. Occasional Papers The Museum Texas Tech University 90:1-12.

Davis, W. B., AND D. J. Schmidry. 1994. The Mammals of Texas. Texas Parks and Wildlife Press, Austin, Texas.

DicE, L. R. 1940. Ecologic and genetic variability within species of Peromyscus. The American Naturalist 74:212-221.

dos Reis, S. F., L. M. Pessoa, And R. E. Strauss. 1990. Application of size-free canonical discriminant analysis to studies of geographic differentiation. Brazilian Journal of Genetics 13:509-520.

Dragoo, J. W., J. A. Lackey, K. E. Moore, E. P. Lessa, J. A. Сook, And T. L. Yates. 2006. Phylogeography of the deer mouse (Peromyscus maniculatus) provides a predictive framework for research on hantaviruses. Journal of General Virology 87:1997-2003.

Drebot, M.A., I. Gavrilovskaya, E. R. Mackow, Z. Chen, R. Lindsay, A. J. Sanchez, S. T. Nichol, And H. Artsob. 2001. Genetic and serotypic characterization of Sin Nombre-like viruses in Canadian Peromyscus maniculatus mice. Virus Research 75:75-86.

Feldhamer, G. A., J. E. Gates, and J. H. Howard. 1983. Field identification of Peromyscus maniculatus and P. leucopus in Maryland: reliability of morphological characters. Acta Theriologica 27:417-423.

Gehlbach, F. R. 1991. The east-west transition zone of terrestrial vertebrates in central Texas: a biogeographical analysis. Texas Journal of Science 43:415-427.

Gering, E. J., J. C. Opazo, And J. F. Storz. 2009. Molecular evolution of cytochrome $b$ in high- and low-altitude deer mice (genus Peromyscus). Heredity 102: 226-235.

GouLD, S. J. 1966. Allometry and size in ontogeny and phylogeny. Biological Review 41:587-640.

Greenbaum, I. F., S. E. Chirhart, M. L. Walker, and R. L. Honeycutt. 2017. Molecular phylogenetics of western deer mice (Peromyscus): taxonomic and biogeographic implications. The Southwestern Naturalist 62:129-137.

Greenbaum, I. F., R. L. Honeycutt, and S. E. Chirhart. 2019. Taxonomy and phylogenetics of the Peromyscus maniculatus species group. Pp. 559-575 in From field to laboratory: a memorial volume in honor of Robert J. Baker (R. D. Bradley, H. H. Genoways, D. J. Schmidly, and L. C. Bradley, eds.). Special Publications, Museum of Texas Tech University 71:xi+1-911.

Grieco, T. M., AND O. T. Rızk. 2010. Cranial shape varies along an elevation gradient in Gambel's white-footed mouse (Peromyscus maniculatus gambelii) in the Grinnell Resurvey Yosemite Transect. Journal of Morphology 271:897-909.

HaLL, E.R. 1981. The Mammals of North America. $2^{\text {nd }}$ edition. John Wiley \& Sons, Inc., New York, U.S.A.

Harney, B. A., ANd R. D. Dueser. 1987. Vertical stratification of activity of two Peromyscus species: an experimental analysis. Ecology 68:1084-1091.

Holmes, M. W., G. K. Boykins, R. C. Bowie, And E. A. Lacey. 2016. Cranial morphological variation in Peromyscus maniculatus over nearly a century of environmental change in three areas of California. Journal of Morphology 277:96-106.

Kalkvik, H. M., I. J. Stout, T. J. Doonan, ANd C. L. Parkinson. 2012. Investigating niche and lineage diversification in widely distributed taxa: phylogeography and ecological niche modeling of the Peromyscus maniculatus species group. Ecography 35:54-64. 
Kamler, J. F., D. S. Pennock, C. Welch, and R. J. Pierotti. 1998. Variation in morphological characteristics of the white-footed mouse (Peromyscus leucopus) and the deer mouse (P. maniculatus) under allotopic and syntopic conditions. The American Midland Naturalist 140:170-179.

KınG, J. A. 1968. Biology of Peromyscus (Rodentia). Special Publication No. 2. The American Society of Mammalogists, Stillwater, Oklahoma.

Kirkland, G. L., AND J. N. Layne (eds.). 1989. Advances in the study of Peromyscus (Rodentia). Texas Tech University Press, Lubbock, Texas.

Koh, H. S., ANd R. L. Peterson. 1983. Systematic studies of deer mice, Peromyscus maniculatus Wagner (Cricetidae, Rodentia): Analysis of age and secondary sexual variation in morphometric characters. Canadian Journal of Zoology 61:2618-2628.

Larson, S. R., X. Lee, and S. M. Paskewitz. 2018. Prevalence of tick-borne pathogens in two species of Peromyscus mice common in northern Wisconsin. Journal of Medical Entomology 55:1002-1010.

Lawing, A. M., AND P.D. Polly. 2010. Geometric morphometrics: Recent applications to the study of evolution and development. Journal of Zoology 280:1-7.

Lewarch, C.L., and H. E. Hoekstra. 2018. The evolution of nesting behaviour in Peromyscus mice. Animal Behaviour 139:103-115.

Lindquist, E. S., C. F. Aquadro, D. McClearn, and K. J. McGowan. 2003. Field identification of the mice Peromyscus leucopus noveboracensis and P. maniculatus gracilis in central New York. Canadian Field Naturalist 117:184-189.

Lucid, M. K. AND J. A. Cook. 2007. Cytochrome- $b$ haplotypes suggest an undescribed Peromyscus species from the Yukon. Canadian Journal of Zoology 85:916-919.

Mclean, B. S., K. C. Bell, J. L. Dunnum, B. Abrahamson, J. P. Colella, E. R. Deardorff, J. A. Weber, A. K. Jones, F. Salazar-MlRALLeS, AND J. A. COok. 2016. Natural history collections-based research: progress, promise, and best practices. Journal of Mammalogy 97:287-297.

Miller, S. E., L. N. Barrow, S. M. Ehlman, J. A. Goodheart, S. E. Greiman, H. L. Lutz, T. M. Misiewicz, S. M. Smith, M. Tan, C. J. Thawley, J. A. CoOK, AND J. E. Light. 2020. Building natural history collections for the $21^{\text {st }}$ century and beyond. Bioscience 70:674-687.

Miluien, V., R. Ledevin, C. BouÉ, And A. Gonzalez. 2017. Rapid morphological divergence in two closely related and Co-occurring species over the last 50 years. Evolutionary Ecology 31:847-64.

Musser, G. G., And M. D. Carleton. 1993. Family Muridae. In "Mammal Species of the World" (D. E. Wilson and D. M. Reeder, eds.). pp. 501-755. Smithsonian Institution Press, Washington, DC.

Myers, P., B. L. Lundrigan, B. W. Gillepsie, and M. L. Zelditch. 1996. Phenotypic plasticity in skull and dental morphology in the prairie deer mouse (Peromyscus maniculatus bairdii). Journal of Morphology 229:229-237.

Oliver, J., R. G. Means, S. Kogut, M. Prusinski, J. J. Howard, L. J. Layne, F. K. Chu, A. Reddy, L. Lee, and D. J. White. 2006. Prevalence of Borrelia burgdorferi in small mammals in New York State. Journal of Medical Entomology 43:924-935.
Osgood, W. H. 1909. Revision of the mice of the American genus Peromyscus. North American Fauna 28:1-285.

Palas, J. S., O. A. Schwartz, ANd A. M. Vivas. 1992. Identification of lowa Peromyscus using external measurements and salivary amylase. Prairie Naturalist 24:273-277.

Pergams, O. R. W., And M. V. Ashley. 1999. Rapid morphological change in Channel Island deer mice. Evolution 53:1573-1581.

Pergams, O. R. W., ANd R. C. LACY. 2008. Rapid morphological and genetic change in Chicago-area Peromyscus. Molecular Ecology 17:450-463.

Platt, R. N., B. R. Amman, M. S. Keith, C. W. Thompson, and R. D. Bradley. 2015. What is Peromyscus? Evidence from nuclear and mitochondrial DNA sequences suggests the need for a new classification. Journal of Mammalogy 96:708-719.

Rand, P. W., E. H. Lacombe, R. P. Smith JR., S. M. RICH, C. W. KILpatrick, C. A. Dragoni, and D. Caporale. 1993. Competence of Peromyscus maniculatus (Rodentia: Cricetidae) as a reservoir host for Borrelia burgdorferi (Spirochaetares: Spirochaetaceae) in the wild. Journal of Medical Entomology 30:614-618.

R Core Team. 2020. R: A language and environment for statistical computing. R Foundation for Statistical Computing, Vienna, Austria.

Reed, A. W., P. K. Kennedy, M. L. Beck, and M. L. Kennedy. 2004. Using morphologic characters to identify Peromyscus in sympatry. The American Midland Naturalist 152:190-195.

Rich, S. M., C. W. Kilpatrick, J. L. Shippee, and K. L. Crowell. 1996. Morphological differentiation and identification of Peromyscus leucopus and P. maniculatus in Northeastern North America. Journal of Mammalogy 77:985-991.

Ridenhour, B. J., And M. J. Cramer. 2015. Differentiation of white-footed mice (Peromyscus leucopus) and deer mice (Peromyscus maniculatus) of the upper Midwest using PCR melt curve analysis. Conservation Genetics Resources 7:29-31.

RohLF, F. J. 2001. TPSDig2: a program for landmark development and analysis.

Rohlf, F. J. And L. F. Marcus. 1993. A revolution in morphometrics. Trends in Ecology \& Evolution 8:129-132.

Rohlf, F. J. AND D. Slice. 1990. Extensions of the Procrustes method for the optimal superimposition of landmarks. Systematic Biology 39:40-59.

Rowsey, D. M., L. R. Heaney, and S. A. Jansa. 2019. Tempo and mode of mandibular shape and size evolution reveal mixed support for incumbency effects in two clades of island-endemic rodents (Muridae: Murinae). Evolution 73:1411-1427.

Schmaljohn, A. L., D. Lı, D. L. Negley, D. S. Bressler, M. J. Turell, G. W. Korch, M. S. Ascher, and C. S. Schmaljohn. 1995. Isolation and initial characterization of a newfound hantavirus from California. Virology 206:963-972.

Schmidly, D. J. 1983. Texas Mammals East of the Balcones Fault Zone. Texas A\&M University Press, College Station, Texas.

Schmidly, D. J., AND R. D. Bradley. 2016. The Mammals of Texas. The University of Texas Press, Austin, Texas.

Seifert, V. A., B. J. Clarke, J. P. Crossland, and L. T. Bemis. 2016. A method to distinguish morphologically similar Peromyscus species using extracellular RNA and high-resolution melt analysis. Analytical Biochemistry 508:65-72.

Slice, D. E. 2007. Geometric morphometrics. Annual Review of Anthropology 36:261-281. 
Smith, H. M., AND H. K. Buechner. 1947. The influence of the Balcones Escarpment on the distribution of amphibians and reptiles in Texas. Bulletin of the Chicago Academy of Sciences 8:1-16.

SMith, M. F., AND J. L. Patton. 1991. Variation in mitochondrial cytochrome $b$ sequence in natural populations in South American akodontine rodents (Muridae: Sigmodontidae). Molecular Biology and Evolution 8:85-103.

Song, J. W., L. J. Baek, J. W. Nagle, D. Schlitter, and R. YanagiHARA. 1996. Genetic and phylogenetic analyses of hantaviral sequences amplified from archival tissues of deer mice (Peromyscus maniculatus nubiterrae) captured in the eastern United States. Archives of Virology 141:959-967.

Stephens, R. B., E. M. Anderson, S. R. Wendt, and J. K. Meece. 2014. Field identification of sympatric Peromyscus leucopus noveboracensis and $P$. maniculatus gracilis in Wisconsin from external characters. The American Midland Naturalist 171:139-146.

Sternburg, J. E., and A. Feldhamer. 1997. Mensural discrimination between sympatric Peromyscus leucopus and Peromyscus maniculatus in southern Illinois. Acta Theriologica 42:1-13.

Stromberg, M. R. 1979. Field identification of Peromyscus leucopus and $P$. maniculatus with discriminant analysis. Transactions of the Wisconsin Academy of Sciences, and Arts Letters 67:159-164.

Tessier, N., S. Noël, and F. J. Lapointe. 2004. A new method to discriminate the deer mouse (Peromyscus maniculatus) from the white-footed mouse (Peromyscus leucopus) using species-specific primers in multiplex PCR. Canadian Journal of Zoology 82:1832-1835.

Thompson, T. G., And W. Conley. 1983. Discrimination of coexisting species of Peromyscus in south-central New Mexico. Southwestern Naturalist 28:199-209.

Venables, W. N., And Ripley, B. D. 2002. Modern Applied Statistics with S. Fourth Edition. Springer, New York.

WILKInson, L. 1997. Systat 7.0 for Windows. SPSS, Inc., Chicago, Illinois.

WolfF, J.O. 1996. Coexistence of white-footed mice and deer mice may be mediated by fluctuating environmental conditions. Oecologia 108:529-533.

Zelditch, M. L., D. L. SWidersKI, AND H. D. Sheets. 2012. Geometric morphometrics for biologists: a primer. San Diego, CA: Elsevier Academic Press.

Zheng, Z., B. S. Arbogast, and G. J. Kenagy. 2003. Historical demography and genetic structure of sister species: deermice (Peromyscus) in the North American temperate rain forest. Molecular Ecology 12:711-724.

Associated editor: Lisa and Robert Bradley

Submitted: January 31, 2021; Reviewed: March 16, 2021

Accepted: April 13, 2021; Published on line:May 28, 2021. 


\section{Supplementary material 1}

List of specimens genetically-identified to species and used in traditional and geometric morphometric analyses. Collection and catalog number are indicated (ASNHC = Angelo State University Natural History Collections; TCWC = Biodiversity Teaching and Research Collections at Texas A\&M University; TTU = Natural Science Research Laboratory, the Museum at Texas Tech University) as is tissue type, GenBank number ("N/A" indicates those specimens from which genetic data were not collected), identification based on the collector or museum (Museum ID), identification based on molecular laboratory work (Genetic ID), sex ( $F=$ female, $M=$ male, $U=$ unknown), year collected, state, county, and locality. Raw data for cranial and external morphological characters are listed for each specimen. Four main datasets were analyzed in this study: traditional morphological analyses including and excluding external characters (Traditional Cranial and External and Traditional Cranial Only, respectively) and geometric morphometics of the ventral and laterial cranial views (Geometric Morphometrics Ventral and Geometric Morphometrics Lateral, respectively). Specimens included in each dataset are indicated with an "X".

\section{https:/www.revistas-conacyt.unam.mx/therya/index.php/THERYA/downloadFile/1116/882}




\section{Appendix 1}

Anatomical definitions of geometric morphometric landmark locations. See Figure 2 for placement of landmark locations.

\begin{tabular}{|c|c|c|}
\hline Orientation & Number & Definition \\
\hline Ventral & 1 & Medial I1 alveolus \\
\hline Ventral & 2 & Lateral I1 alveolus \\
\hline Ventral & 3 & Anterior edge of incisive foramen \\
\hline Ventral & 4 & Suture of premaxilla and maxilla bones \\
\hline Ventral & 5 & Maxilla-rostral connection point \\
\hline Ventral & 6 & Anterior margin of zygomatic arch \\
\hline Ventral & 7 & Posterior edge of incisive foramen \\
\hline Ventral & 8 & Anterior edge of $\mathrm{M} 1$ alveolus \\
\hline Ventral & 9 & Posterior edge of $\mathrm{M} 1$ alveolus \\
\hline Ventral & 10 & Anterior edge of posterior foramen palatine \\
\hline Ventral & 11 & Posterior edge of $\mathrm{M} 3$ alveolus \\
\hline Ventral & 12 & Posterior edge of palatine bone \\
\hline Ventral & 13 & Anterior curvature of squamosal \\
\hline Ventral & 14 & Medial, anterior edge of foramen ovale \\
\hline Ventral & 15 & Lateral suture of basisphenoid and basioccipital at tympanic bulla \\
\hline Ventral & 16 & Medial suture of basisphenoid and basioccipital bones \\
\hline Ventral & 17 & Medial posterior edge of foramen magnum \\
\hline Ventral & 18 & Lateral edge of foramen magnum \\
\hline Lateral & 1 & Posterior edge of 11 alveolus \\
\hline Lateral & 2 & Anterior edge of $\mathrm{I} 1$ alveolus \\
\hline Lateral & 3 & Anterior-most tip of nasal bone \\
\hline Lateral & 4 & Ventral-most edge of zygomatic arch \\
\hline Lateral & 5 & Suture of the nasal and frontal bones \\
\hline Lateral & 6 & Dorsal-most edge of zygomatic arch \\
\hline Lateral & 7 & Anterior edge of $\mathrm{M} 1$ alveolus \\
\hline Lateral & 8 & Posterior edge of M1alveolus \\
\hline Lateral & 9 & Posterior edge of $\mathrm{M} 3$ alveolus \\
\hline Lateral & 10 & Ventral tip of pterygoid process \\
\hline Lateral & 11 & Posterior edge of zygomatic arch, concave-most point \\
\hline Lateral & 12 & Ventral-most tip of squamosal and parietal bone suture \\
\hline Lateral & 13 & Suture of the interparietal and occipital bones \\
\hline Lateral & 14 & Concave-most point of the occipital condyle, posterior-most point \\
\hline
\end{tabular}




\section{Appendix 2}

Allometric size-shape relationship in the geometric morphometric datasets across PC1-10 of the lateral view (a-j) and the ventral view (k-t). Percents labeled on the $y$-axis indicate the amount of total variation explained by each PC. Blue $=$ Peromyscus leucopus and red = P. maniculatus.
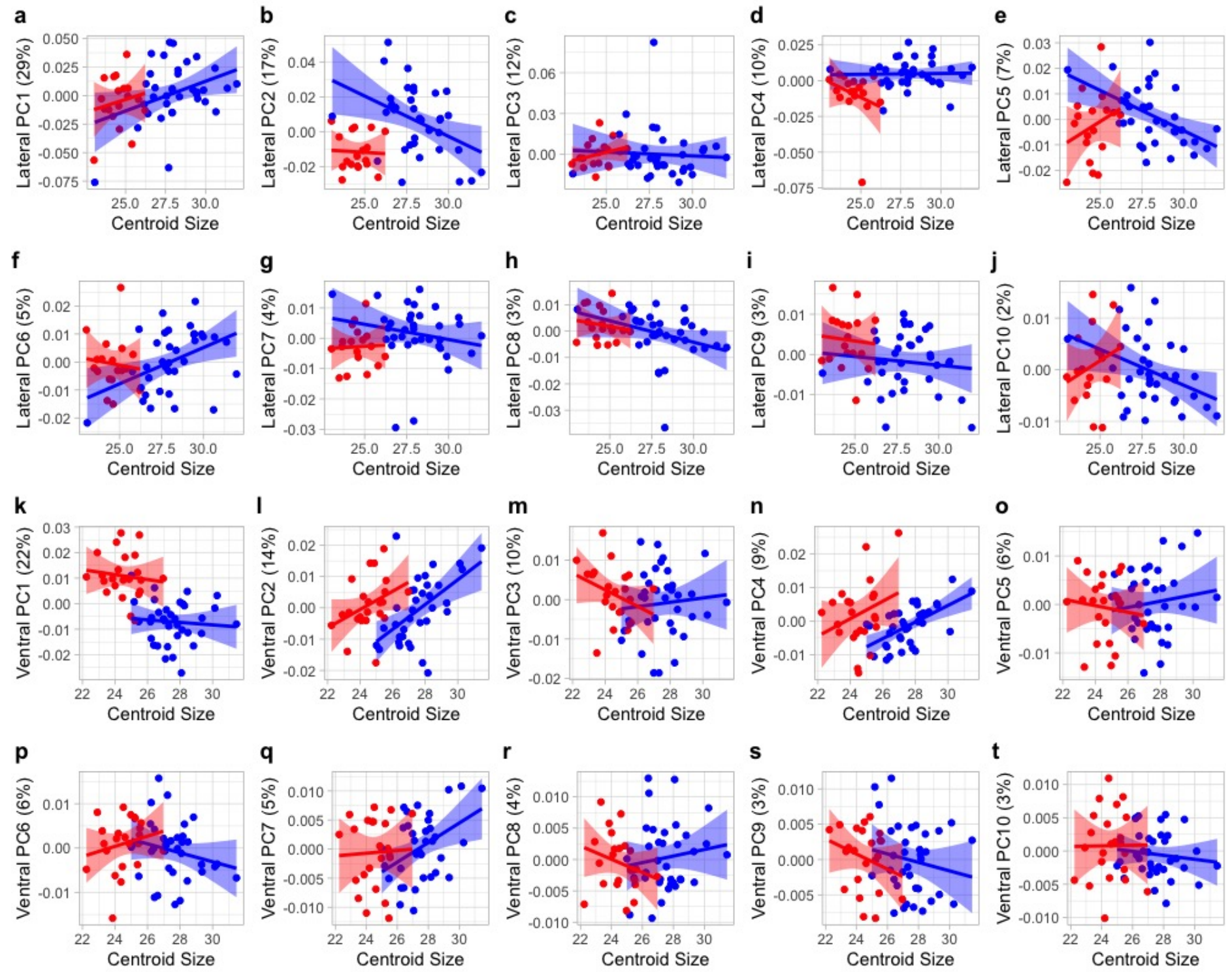


\section{Appendix 3}

Welch's two-sample t-test results of traditional morphometric trait differences between $P$. leucopus and $P$. maniculatus (see text for definitions of abbreviations). P-values represent Bonferroni-corrections. $P$-value: $0.01-0.05^{*}, 0.001-0.01^{* *}, 0-0.001^{* * *}$

\begin{tabular}{llrr}
\hline & \multicolumn{1}{c}{ Trait } & \multicolumn{1}{c}{ t-value } & \multicolumn{1}{l}{ P-value } \\
\hline Cranial Traits & DB & 8.28 & $1.85 \mathrm{e}-9^{* * *}$ \\
& DIA & 6.64 & $5.90 \mathrm{e}-7^{* * *}$ \\
& IFL & 0.05 & 1 \\
& IOC & 6.43 & $3.42 \mathrm{e}-6^{* * *}$ \\
& LAB & 0.57 & 1 \\
& MB & 7.63 & $1.25 \mathrm{e}-7^{* * *}$ \\
& MTR & 5.34 & $7.08 \mathrm{e}-5^{* * *}$ \\
& NL & 4.58 & $4.63 \mathrm{e}-4^{* * *}$ \\
& OIL & 9.84 & $2.47 \mathrm{e}-11^{* * *}$ \\
& ONL & 10.74 & $5.04 \mathrm{e}-13^{* * *}$ \\
& PPL & 6.04 & $4.08 \mathrm{e}-6^{* * *}$ \\
& RW & 6.60 & $4.84 \mathrm{e}-7^{* * *}$ \\
& ZB & 6.68 & $7.57 \mathrm{e}-7^{* * *}$ \\
& EL & 5.01 & $9.66 \mathrm{e}-5^{* * *}$ \\
& HL & 7.62 & $1.63 \mathrm{e}-8^{* * *}$ \\
& TL:TBL & 9.59 & $2.20 \mathrm{e}-10^{* * *}$ \\
\hline
\end{tabular}

\section{Appendix 4}

Traditional morphometric principal component factor loadings. Percentages represent the proportion of variance associated with each PC axis. See text for definitions of abbreviations of cranial and external traits. Factor loadings in bold indicate high loading values.

\begin{tabular}{|c|c|c|c|c|c|c|c|c|c|c|c|c|c|c|c|c|c|}
\hline & & PC1 & PC2 & PC3 & PC4 & PC5 & PC6 & PC7 & PC8 & PC9 & PC10 & PC11 & PC12 & PC13 & PC14 & PC15 & PC16 \\
\hline \multicolumn{2}{|c|}{ Percent of Variation } & 60.81 & 9.75 & 5.51 & 3.75 & 3.72 & 3.23 & 2.56 & 2.35 & 2.05 & 1.71 & 1.38 & 1.15 & 1.08 & $5.8 e-3$ & $2.7 e-3$ & $9.1 e-4$ \\
\hline \multicolumn{2}{|c|}{ Eigenvalues } & 9.73 & 1.56 & 0.88 & 0.60 & 0.60 & 0.52 & 0.41 & 0.38 & 0.33 & 0.27 & 0.22 & 0.18 & 0.17 & 0.09 & 0.04 & 0.01 \\
\hline Cranial & DB & -0.27 & -0.03 & -0.29 & 0.14 & -0.10 & -0.07 & 0.21 & -0.35 & 0.24 & 0.48 & -0.20 & 0.28 & 0.10 & -0.47 & 0.07 & 0.03 \\
\hline \multirow[t]{12}{*}{ Traits } & DIA & -0.26 & 0.15 & 0.28 & -0.16 & -0.41 & 0.12 & 0.05 & -0.45 & -0.13 & -0.01 & -0.13 & 0.24 & 0.14 & 0.50 & 0.23 & -0.01 \\
\hline & IFL & -0.13 & -0.57 & 0.20 & -0.23 & -0.47 & -0.26 & -0.19 & 0.38 & 0.13 & 0.22 & 0.13 & 0.06 & -0.02 & 0.01 & -0.02 & $4.7 e-3$ \\
\hline & $10 C$ & -0.26 & -0.15 & -0.33 & 0.05 & 0.15 & 0.31 & -0.03 & 0.14 & 0.59 & -0.22 & 0.11 & 0.04 & 0.26 & 0.41 & -0.08 & 0.06 \\
\hline & $\mathrm{LAB}$ & -0.14 & -0.59 & 0.16 & 0.05 & 0.37 & 0.12 & -0.38 & -0.33 & -0.25 & -0.21 & -0.24 & -0.15 & -0.09 & 0.05 & -0.07 & -0.02 \\
\hline & MB & -0.28 & -0.01 & -0.22 & 0.16 & -0.23 & 0.05 & 0.16 & -0.15 & 0.08 & 0.07 & 0.08 & -0.32 & -0.77 & 0.13 & -0.07 & 0.01 \\
\hline & MTR & -0.23 & -0.18 & -0.44 & 0.34 & -0.19 & -0.01 & 0.17 & 0.15 & -0.56 & -0.02 & 0.11 & -0.16 & 0.35 & 0.02 & 0.21 & 0.03 \\
\hline & $\mathrm{NL}$ & -0.23 & -0.02 & 0.38 & 0.42 & 0.09 & -0.45 & 0.35 & -0.05 & 0.29 & 0.04 & -0.27 & -0.27 & 0.21 & $4.2 e-3$ & -0.03 & 0.05 \\
\hline & PPL & -0.28 & -0.12 & 0.16 & -0.14 & $-3.7 e-3$ & 0.14 & 0.33 & 0.02 & 0.09 & -0.52 & 0.14 & 0.21 & -0.12 & -0.48 & 0.38 & 0.05 \\
\hline & OIL & -0.31 & 0.06 & 0.03 & -0.16 & 0.02 & 0.02 & 0.17 & 0.03 & -0.23 & -0.03 & -0.02 & 0.21 & 0.04 & -0.07 & -0.67 & 0.54 \\
\hline & ONL & -0.31 & 0.05 & 0.02 & -0.07 & 0.05 & 0.01 & 0.14 & 0.06 & -0.10 & -0.01 & 0.03 & 0.13 & 0.05 & -0.06 & -0.38 & -0.83 \\
\hline & RW & -0.26 & 0.18 & -0.02 & -0.56 & $4.2 \mathrm{e}-3$ & 0.14 & -0.06 & 0.03 & 0.02 & 0.10 & -0.14 & -0.67 & 0.21 & -0.16 & 0.09 & 0.02 \\
\hline & ZB & -0.27 & 0.03 & -0.07 & -0.19 & 0.48 & -0.14 & 0.11 & 0.36 & -0.13 & 0.31 & -0.28 & 0.27 & -0.24 & 0.25 & 0.35 & 0.05 \\
\hline \multirow{3}{*}{$\begin{array}{l}\text { External } \\
\text { Traits }\end{array}$} & $\mathrm{EL}$ & -0.20 & 0.22 & 0.47 & 0.40 & -0.02 & 0.53 & -0.27 & 0.36 & -0.08 & 0.17 & 0.10 & -0.05 & -0.04 & -0.06 & 0.03 & 0.04 \\
\hline & $\mathrm{HL}$ & -0.26 & 0.14 & 0.08 & -0.03 & 0.29 & -0.34 & -0.24 & -0.23 & -0.03 & 0.10 & 0.75 & -0.02 & 0.05 & 0.04 & 0.09 & 0.05 \\
\hline & TL:TBL & -0.22 & 0.34 & -0.15 & 0.09 & -0.18 & -0.38 & -0.54 & 0.18 & $3.8 e-3$ & -0.46 & -0.27 & 0.06 & -0.08 & -0.03 & $4.0 e-3$ & $-3.3 e-3$ \\
\hline
\end{tabular}




\section{Appendix 5}

Complete MANOVA results assessing the morphological differentiation between Peromyscus leucopus and P. maniculatus using allometry-minimized and non-minimized geometric morphometric analyses of the ventral and lateral views of the crania.

\begin{tabular}{lcrrr}
\hline & Df & Wilks & F-Statistic & p-value \\
\hline Ventral View (Allometry minimized) & 1 & 0.63 & 0.34 & 0.99 \\
Ventral View (Non-allometry minimized) & 1 & 0.07 & 8.27 & $1.9 \mathrm{e}-6^{* * *}$ \\
Lateral View (Allometry minimized) & 1 & 0.64 & 0.49 & 0.97 \\
Lateral View (Non-allometry minimized) & 1 & 0.12 & 6.44 & $8.1 \mathrm{e}-6^{* * *}$ \\
$P$-value significance: $0.01-0.05^{*}, 0.001-0.01^{* *}, 0-0.001^{* * *}$ & & & & \\
\hline
\end{tabular}

\section{Appendix 6}

Centroid sizes of P. leucopus and P. maniculatus. a) Ventral view geometric morphometric dataset, b) Lateral view geometric morphometric dataset. Blue $=$ Peromyscus leucopus and red $=$ P. maniculatus.

a

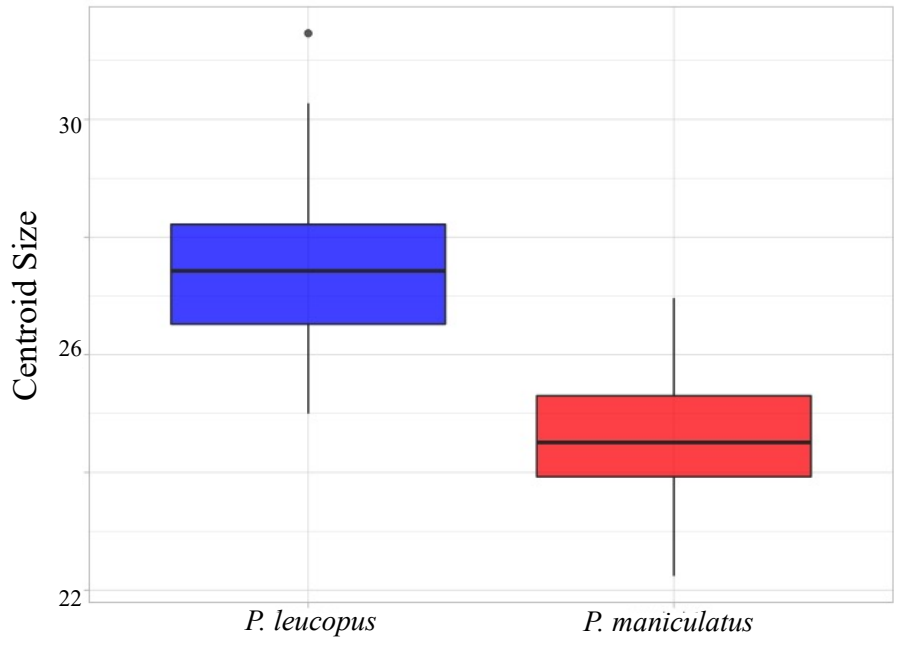

$\mathrm{b}$

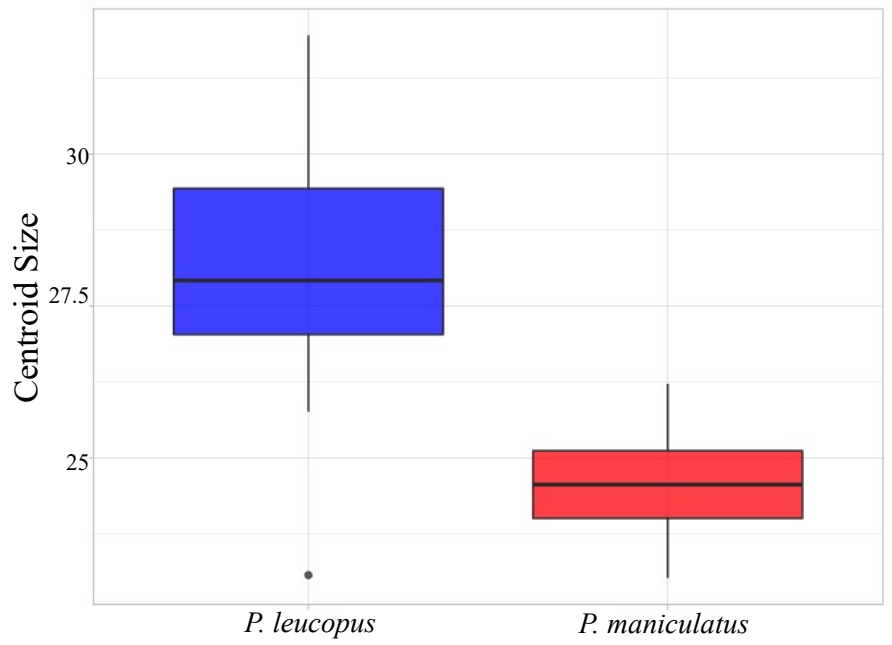

\section{Appendix 7}

Principal Component Analysis of traditional morphometric characters depicting PC2 and PC3. a) Traditional morphometric dataset including both cranial and external characters, b) Traditional morphometric dataset including cranial characters only. Blue $=$ Peromyscus leucopus and red $=P$. maniculatus; asterisks represent significant morphological differences at a PC axis as assessed with an ANOVA. P-value: 0.01-0.05*, 0.001-0.01**, 0-0.001*** where NS indicates non-significance.

a

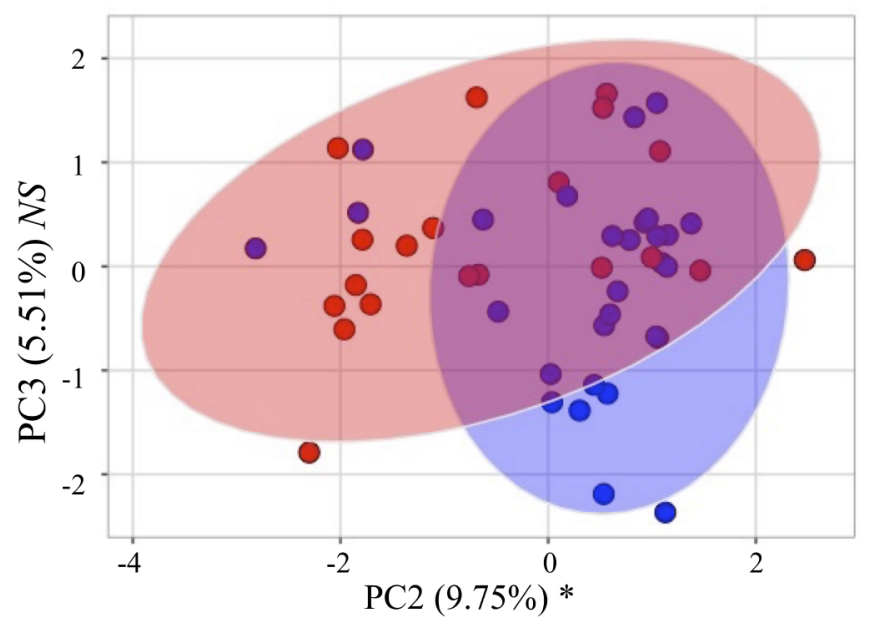

$\mathrm{b}$

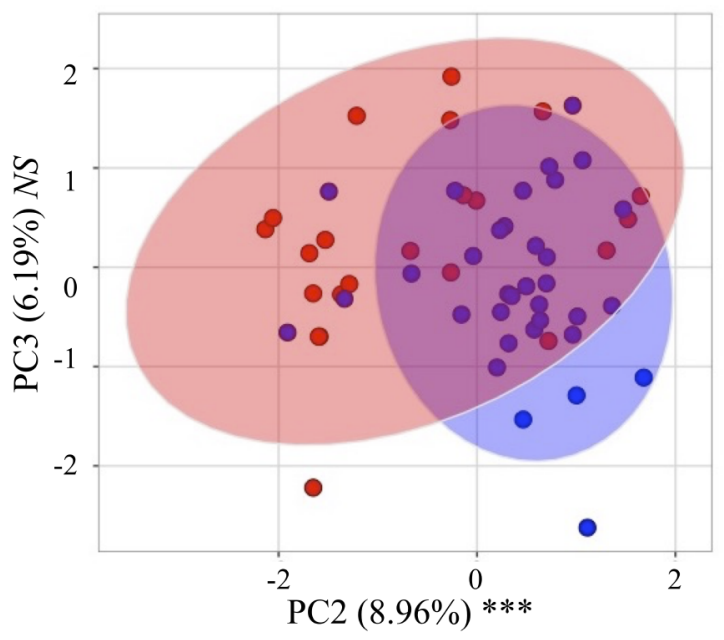


PEROMYSCUS LEUCOPUS AND P. MANICULATUS IN EAST TEXAS

388 THERYA Vol. 12 (2): 369-387 